\title{
Identification, expression and variation of GNPDA2 gene, and its association with body weight and fatness traits in chicken
}

Hongjia Ouyang, Huan Zhang, Weimin Li, Sisi Liang, Endashaw Jebessa, Bahareldin A Abdalla, Qinghua Nie

Background. GNPDA2 (glucosamine-6-phosphate deaminase 2) gene is a member of Glucosamine-6-phosphate (GlcN6P) deaminase subfamily, which encoded an allosteric enzyme of GlcN6P. Genome-wide association studies (GWAS) have shown that variations of human GNPDA2 are associated with body mass index and obesity risk, but its function and metabolic implications remain to be elucidated. The object of this study was to characterize the gene structure, expression, and biological functions of GNPDA2 in chickens. Methods. Variant transcripts of chicken GNPDA2 and their expression were investigated using rapid amplification of CDNA ends (RACE) system and real-time quantitative PCR technology. We detected the GNPDA2 expression in hypothalamic, adipose, and liver tissue of Xinghua chickens with fasting and high-glucose-fat diet treatments, and performed association analysis of variations of GNPDA2 with productive traits in chicken. The function of GNPDA2 was further studied by overexpression and small interfering RNA (siRNA) methods in chicken preadipocytes. Results. Four chicken GNPDA2 transcripts (cGNPDA2-a cGNPDA2-d) were identified in this study. The complete transcript GNPDA2-a was predominantly expressed in adipose tissue (subcutaneous fat and abdominal fat), hypothalamus, and duodenum. In fasting chickens, the mRNA level of GNPDA2 was decreased by $58.8 \%(P<0.05)$ in hypothalamus, and returned to normal level after refeeding. Chicken fed a high-glucose-fat diet increased GNPDA2 gene expression about 2 -fold higher in adipose tissue $(P<0.05)$ than that in the control (fed a basal diet), but decreased its expression in hypothalamus. Two single-nucleotide polymorphisms of the GNPDA2 gene were significantly associated with body weight and a number of fatness traits in chicken $(P<0.05)$. Conclusion. Our findings indicated that the GNPDA2 gene have a potential roles in the regulation of body weight, fat and energy metabolism in chickens. 
1 Identification, expression and variation of GNPDA2 gene, and its association with body

2 weight and fatness traits in chicken

3

4 Hongjia Ouyang1, 2, Huan Zhang1, 2, Weimin Li1 ${ }^{1,2}$, Sisi Liang1, 2, Endashaw Jebessa ${ }^{1,}$,

5 Bahareldin Ali Abdalla ${ }^{1,2}$, Qinghua $\mathrm{Nie}^{1,2 *}$

6

$7{ }^{1}$ Department of Animal Genetics, Breeding and Reproduction, College of Animal Science, South

8 China Agricultural University, Guangzhou, Guangdong, China. ${ }^{2}$ Guangdong Provincial Key Lab

9 of Agro-Animal Genomics and Molecular Breeding and Key Lab of Chicken Genetics, Breeding

10 and Reproduction, Ministry of Agriculture, Guangzhou, Guangdong, China.

11

12

*Corresponding author: Qinghua Nie (Tel. 86 20-85285759. Fax.86 20-85280740. E-mail: nqinghua@scau.edu.cn).

14

Running head: Characterization of chicken GNPDA2 gene 
17

\section{Abstract}

Background. GNPDA2 (glucosamine-6-phosphate deaminase 2) gene is a member of Glucosamine-6-phosphate (GlcN6P) deaminase subfamily, which encoded an allosteric enzyme of GlcN6P. Genome-wide association studies (GWAS) have shown that variations of human GNPDA2 are associated with body mass index and obesity risk, but its function and metabolic implications remain to be elucidated. The object of this study was to characterize the gene structure, expression, and biological functions of GNPDA2 in chickens.

Methods. Variant transcripts of chicken GNPDA2 and their expression were investigated using rapid amplification of cDNA ends (RACE) system and real-time quantitative PCR technology. We detected the GNPDA2 expression in hypothalamic, adipose, and liver tissue of Xinghua chickens with fasting and high-glucose-fat diet treatments, and performed association analysis of variations of GNPDA2 with productive traits in chicken. The function of GNPDA2 was further studied by overexpression and small interfering RNA (siRNA) methods in chicken preadipocytes. Results. Four chicken GNPDA2 transcripts (cGNPDA2-a c GNPDA2-d) were identified in this study. The complete transcript GNPDA2-a was predominantly expressed in adipose tissue (subcutaneous fat and abdominal fat), hypothalamus, and duodenum. In fasting chickens, the mRNA level of GNPDA2 was decreased by 58.8\% $(P<0.05)$ in hypothalamus, and returned to normal level after refeeding. Chicken fed a high-glucose-fat diet increased GNPDA2 gene expression about 2 -fold higher in adipose tissue $(P<0.05)$ than that in the control (fed a basal diet), but decreased its expression in hypothalamus. Two single-nucleotide polymorphisms of the GNPDA2 gene were significantly associated with body weight and a number of fatness traits in chicken $(P<0.05)$.

Conclusion. Our findings indicated that the GNPDA2 gene have a potential roles in the regulation of body weight, fat and energy metabolism in chickens. 


\section{Introduction}

Obesity is a common nutritional disorder and increase risk of several diseases, such as hypertension, cardiovascular disease and type II diabetes (Kopelman. 2000; Flegal et al., 2007; Finkelstein et al., 2008). It becomes a major public health problem, because of it has dramatically increased worldwide during the past years. Obesity is modulated by environmental and genetic factors. The modern environment contributes to the increasing prevalence of obesity, but genetic factors modulate the susceptibility of each individual (Maes, Neale \& Eaves, 1997; Barsh, Farooqi \& O’Rahilly, 2000).

GNPDA2 gene encoded an allosteric enzyme of Glucosamine-6-phosphate deaminase (GlcN6P), which can catalyzes the reversible conversion of D-glucosamine-6-phosphate into Dfructose-6-phosphate and ammonium (Arreola et al., 2003). The GlcN6P enzyme was initially characterized in pig kidney; it has been also identified in a variety of organisms (Leloir \& Cardini, 1956). This enzyme was annotated include hydrolase activity and glucosamine-6phosphate deaminase activity, and related the pathways of metabolism and amino sugar and nucleotide sugar metabolism. The SNP near the human GNPDA2 gene (rs10938397) was first identified to be associated with both body mass index (BMI) and weight in adult of European by GWAS in 2009 (Willer et al., 2009), and then it was confirmed in adult of various populations, including Europeans, Americans, East Asians and Arabians (Hotta et al., 2009; Speliotes et al., 2010; Wen et al., 2012; Gong et al., 2013; Tomei et al., 2015). The variations of GNPDA2 were also found to be associated with BMI or risk of obesity in children and old age population (Elks et al., 2010; Mejia-Benitez et al., 2013; Murphy et al., 2013; Xi et al., 2013a; Pillay et al., 2015). Furthermore, it also modulated the susceptibility of hypertension and type II diabetes (Takeuchi et al., 2011; Robiou et al., 2013; Xi et al., 2013b; Xi et al., 2014; Kong et al., 2015).

Fatness traits are important economic traits in chickens because of its relation to meat quality of broiler, suitable content of fat can improve the meat quality (tenderness, juiciness and flavor), but excess fat deposition can greatly reduce the meat quality (Castellini et al, 2002; Zerehdaran et al, 2004; Petracci et al, 2013). In addition, large amounts of fat deposition also can reduce the 
68

69

feed efficiency, even increased the risk of disease in chicken (Boekholt et al, 1994). In human, GNPDA2 has been found to be associated with BMI and fat deposition, but the characteristics and functions of GNPDA2 in chickens have not been reported. In this study, we hypothesize that GNPDA2 is also involved in body weight gain and fat mass accumulation in chickens. Therefore, we identified the chicken GNPDA2 gene and monitored its mRNA level in various tissues under different conditions of nutrition, and performed association analysis of variations of GNPDA2 with fatness traits in chickens, so as to characterize the functions of GNPDA2 gene in fat metabolism in chickens.

\section{Materials and Methods}

\subsection{Animals and DNA samples}

A total of 45 Xinghua chickens (20 chickens $\{10$ males and 10 females $\}$ at 14 weeks of age; 25 female chickens at 23 weeks of age) were obtained from Poultry Farm of the South China Agricultural University (SCAU). All birds were raised in individual cages, kept in identical light/dark cycles and had ad libitum access to water throughout the experimental period. Birds were allocated to the one of three different treatments (T) as follows: T1, the 14-weeks-old chickens were divided into two groups (in each group; $\mathrm{n}=10,5$ males and 5 females) and fed a high-glucose-fat diet (Table S1) or a basal diet for 4 weeks, respectively. T2, the23-weeks-old chickens with significant different body weight were divided into high body weight group ( $\mathrm{n}=5$, $1388.5 \pm 122.4 \mathrm{~g})$ and low body weight group $(\mathrm{n}=5,1132.7 \pm 108.5 \mathrm{~g})$. In T3, the remain 1523 weeks-old female chickens were divided into three groups of five birds each and subjected to the following treatments: (I) Fed a basal diet ad libitum (Control); (II) Fasted for 2 days (Fasted); (III) Fasted for 2 days and refed a basal diet for 1 day (Re-Fed).

The DNA samples from an $\mathrm{F}_{2}$ resource population which derived from reciprocal crossed between Xinghua (XH) and White Recessive Rock (WRR) chickens were used for GNPDA2 variations identifying and association analysis (Lei et al., 2005). The population was made up of 17 full-sibling families, which had 434 F2 individuals (221 male and 213 female chickens) with 
94 a detailed record of growth traits, carcass traits, and meat quality traits.

95

96

\subsection{Primers and siRNA}

All primers were designed using Premier Primer 5.0 software (Premier Bio-soft International, Palo Alto, CA, USA) and synthesized by Biosune Co. Ltd (Shanghai, China). Primers G1 and G2 were used to clone cGNPDA2. G5'-outer and G5'-inner were used for 5'RACE PCR, G3'-outer and G3'-inner were used for 3'RACE PCR. G3 and G4 were used for real-time-PCR analysis of chicken GNPDA2 and $\beta$-actin, respectively. Primers G5-G11 were used to identify and genotype SNPs of cGNPDA2. All SR1 SR3 siRNAs were synthesized by GenePharma Co. Ltd (Suzhou, China). Scrambled siRNA was also synthesized as negative control. Primers of GNPDA2 are summarized in Table S2. Primers for real time quantity PCR (RT-qPCR) of other GNPDA2related genes are summarized in Table S3.

\subsection{RNA isolation, cDNA synthesis and Real time PCR analysis}

Upon termination of the experiment, chickens were euthanized and 16 tissues (cerebrum, cerebellum, hypothalamus, pituitary, abdominal fat, subcutaneous fat, breast muscle, heart, liver, spleen, lungs, kidney, muscular stomach, glandular stomach, duodenum and ovary/testis) were rapidly collected, immediately frozen in liquid nitrogen and stored at $-80{ }^{\circ} \mathrm{C}$ prior to use. Total RNA was isolated using Trizol reagent (Invitrogen, Foster City, CA, USA), following the recommended manufacturer's protocol. The quality and quantity of RNA samples were detected by $1.5 \%$ agarose gel electrophoresis and based on absorbance OD (optical density) at 260/280 $\mathrm{nm}$ ratio, respectively. For the cDNA synthesis, $2 \mu \mathrm{g}$ total RNA was subjected to reverse transcription with the use of oligo $(\mathrm{dT})_{18}$ as the primer and reverse transcriptase was performed using RevertAid ${ }^{\mathrm{TM}}$ First Strand cDNA Synthesis Kit (Fementas, Waltham, MA, USA) in total 20 $\mu \mathrm{L}$ reaction volume. The relative quantity of mRNA was detected using SsoFast Eva Green Supermix (BIO-RAD, Hercules, USA) in a final volume of $20 \mu \mathrm{L}$ and performing in CFX9600 (BIO-RAD) under the following conditions: $95{ }^{\circ} \mathrm{C}$ for $3 \mathrm{~min}$, followed by 40 cycles of $10 \mathrm{~s}$ at 95 
$119{ }^{\circ} \mathrm{C}, 30 \mathrm{~s}$ at annealing temperature $\left(58-62{ }^{\circ} \mathrm{C}\right), 30 \mathrm{~s}$ at $72{ }^{\circ} \mathrm{C}$ and melt curve by $65{ }^{\circ} \mathrm{C}$ to $95{ }^{\circ} \mathrm{C}$, 120 increment $0.5^{\circ} \mathrm{C}$ for $5 \mathrm{~s}$. Each sample was assayed in triplicate, and chicken $\beta$-actin was used as 121 reference gene. The specificity of product was decided by the solubility curve, and the 122 quantitative values were obtained from the threshold PCR quantification cycle $(\mathrm{Cq})$. The relative 123 mRNA level in each sample was calculated using comparative equation $2^{-\Delta \mathrm{Ct}}\left(\Delta \mathrm{Ct}=\mathrm{Ct}_{\text {target gene }}-\right.$ $124 \mathrm{Ct}_{\text {B-actin }}$ ) (PCR efficiency was considered as 100\%) by CFX Manager software (version 2.1). 125 Fold-change values were calculated using comparative $2^{-\Delta \Delta \mathrm{Ct}}(\Delta \Delta \mathrm{Ct}=\Delta \mathrm{Ct}$ target sample $-\Delta \mathrm{Ct}$ control 126 sample) method.

127

128

\section{$2.45^{\prime} R A C E$ and $3^{\prime} R A C E$ PCR}

The RACE system was performed to obtain the full-length cDNA sequence of chicken GNPDA2. The hypothalamus and adipose tissue total RNA were used as template for RACE PCR. RACE PCR was performed with the SMARTer RACE cDNA Amplification Kit (Clontech, Osaka, Japan) following the manufacturer's instructions. Products of RACE PCR were cloned into pMD-18T vector (Takara, Osaka, Japan) according to the manufacturer's protocol, and sequenced by Invitrogen Co. Ltd (Guangzhou, China).

\subsection{GNPDA2 sequences blast and phylogenetic analysis}

The GNPDA2 AA sequences of the other 17 species were obtained from Genebank (Table S4). The obtained cDNA sequences were analyzed by BLAST (http: //blast.ncbi.nlm.nih.gov/Blast.cgi). On the basis of the 18 GNPDA2 sequences, a phylogenetic tree was constructed by using Neighbor-joining method of the MEGA 4.1 software (http: //www.megasoftware.net/mega41.html).

\subsection{SNP identification and genotyping}

Variations of $c G N P D A 2$ were identified and genotyped in DNA samples of $\mathrm{F}_{2}$ resource population (XH\&WRR) using PCR amplification and sequencing. PCR was performed in 
143

144

145

146

147

148

149

150

151

152

153

154

155

156

157

158

159

160

161

162

163

164

165

166

volume of $50 \mu \mathrm{L}$ of a mixture containing $50 \mathrm{ng}$ of chicken genomic DNA, 10 pmol of primers and $25 \mu \mathrm{L}$ PCR Master Mix (Transgen, Beijing, China), and using the following protocol: $94{ }^{\circ} \mathrm{C}$ for $3 \mathrm{~min}$, followed by 32 cycles of $30 \mathrm{~s}$ at $94{ }^{\circ} \mathrm{C}, 30 \mathrm{~s}$ at annealing temperature $\left(58-62{ }^{\circ} \mathrm{C}\right.$; Supplementary Table S3), $30 \mathrm{~s}$ at $72{ }^{\circ} \mathrm{C}$ and a final extension of $72{ }^{\circ} \mathrm{C}$ for $5 \mathrm{~min}$. PCR products were sequenced by Invitrogen Co. Ltd (Guangzhou, China). PCR-restriction fragment length polymorphism (PCR-RFLP) was also used to genotyping SNPs. PCR products were digested by fasted restriction enzymes (Fementas) following the manufacturer's instructions, and then detected through $2 \%$ agarose gel electrophoresis.

\subsection{Plasmid construction, cell culture and transfection}

The coding sequences of cGNPDA2-a were amplified from chicken abdominal fat cDNA using PCR, and then cloned into pcDNA3.1(+) vector (Invitrogen, Carlsbad, CA) according to the protocols of the manufacturer, using the XhoI and BamHI (Fementas) restriction sites. Chicken preadipocytes were obtained from 20 days old Xinghua chicks as previous study (Ramsay \& Rosebrough, 2003). The cell were maintained in Dulbecco's modified Eagle medium (DMEM)/F-12 (Gibco, Grand Island, NY) supplemented with 10\% (v/v) foetal bovine serum (Hyclone, Logan, UT), and $100 \mu \mathrm{g} / \mathrm{mL}$ penicillin/streptomycin (Invitrogen) at $37^{\circ} \mathrm{C}$ with $5 \%$ $\mathrm{CO}_{2}$, humidified atmosphere. Preadipocytes were seeded in 12 -well plate at a density of $5.0 \times 10^{4}$ cells/well, and were transfected plasmid $(1 \mu \mathrm{g} /$ per well $)$ or siRNA $(50 \mathrm{nM})$ using Lipofectamine 3000 (Invitrogen) $(1 \mu \mathrm{L} /$ per well) when the cells growth reach 70\% 80\% confluence. After $48 \mathrm{~h}$, all cells were collected to assay the mRNA level of GNPDA2 and its related genes. The pcDNA3.1(+) vector without insert and scrambled siRNA were used as an internal control, respectively.

\subsection{Statistical analysis}

All values are presented as means \pm S.E.M. The threshold for significance was set at $P<0.05$ 
167

168

169

170

171

172

173

174

175

176

177

178

179

180

181

182

183

184

185

186

187

188

189

190

191

and for high significance at $P<0.01$. Association analysis of SNPs with productive traits were performed using the General Linear Models Procedures of SAS 9.0 (SAS Institute Inc., Cary, NC, USA) and the genetic effects were analyzed by a mixed procedure according to the following model (Lei et al., 2005):

$$
Y_{i j k l}=\mu+S_{i}+G_{j}+H_{k}+F_{l}+G_{i} * S_{j}+G_{i} * H_{k}+G_{i} * F_{l}+e_{i j k l}
$$

where $Y=$ the traits phenotypic values; $\mu=$ the overall population mean; $S=$ the fixed effect of gender; $G=$ the fixed effect of genotype; $H=$ the fixed effect of hatch; $F=$ the fixed effect of family; $e=$ the random residuals.

\subsection{Animal Ethics}

The experimental procedures used in this study met the guidelines of the Animal Care and Use Committee of the South China Agricultural University (SCAU) (Guangzhou, People's Republic of China) and approved by SCAU with approval number SCAU\#0011. Animal experiments were handled in compliance and all efforts were made to minimize suffering.

\section{Results}

\subsection{The chicken GNPDA2 cDNA and variant transcripts}

Four different GNPDA2 transcripts were identified in chicken in this study, the length of each of them as follows: cGNPDA2-a (NCBI accession number: JX048609) was 1806 bp, cGNPDA2b (JX048610) was 1621 bp, cGNPDA2-c (KF296359) was 1522 bp and cGNPDA2-d (KF296360) was 1715 bp. The results of UCSC genome BLAST showed that the chicken GNPDA2 was 7453 bp long, which located at chromosome 4 and spanned from 67202451 to 67209903. Here, our result cGNPDA2-a, the predominant transcript of GNPDA2, comprised seven exons and six introns. Compared with cGNPDA2-a, cGNPDA2-b was deleted the whole exon5 (185 bp), cGNPDA2-c was deleted the exon5 and part of the exon6 (99 bp), and cGNPDA2-d has a 91 bp deletion in exon2. Exon 5 and 6 are 'hot spots' for alternative splicing (Figure 1A). Due to the deletions located at coding region, four GNPDA2 transcripts have 
192

193

194

195

196

197

198

199

200

201

202

203

204

205

206

207

208

209

210

211

212

213

214

215

216

different open reading frame (ORF). The ORF of cGNPDA2-a was 828 bp and encoding 275 amino acids (AA). The ORF length of the other three cGNPDA2 transcripts were 438 bp for cGNPDA2-b, 435 bp for cGNPDA2-b and 737 bp for cGNPDA2-d, respectively (Figure 1B).

\subsection{Sequence alignment and phylogeny analysis}

GNPDA2 gene is a member of GlcN6P deaminase subfamily. Analysis by using NCBI BLAST (Basic Local Alignment Search Tool) showed that the coding DNA sequences of GNPDA2 were highly conserved, and has conserved domain of GlcN6P deaminase in chicken and other 17 species. The GNPDA2 sequence homology of chicken with other birds and mammalians were all above $90 \%$, especially the homology with duck up to $99.3 \%$ (Figure S1A). The phylogenetic tree based on GNPDA2 homology showed that 18 species were divided into four distinct groups, and they were birds (chicken, turkey, duck, parrot, pigeon, zebra finch and sparrow), mammals (human, cattle, dog, pig, horse, goat, sheep, mouse and rat), frog and zebrafish (Figure S1B).

\subsection{SNPs identification and its association analysis with productive traits}

Chicken GNPDA2 was located at chromosome 4 and spanned in 7453 bp (NC_006091.3). In $\mathrm{F}_{2}$ resource population (XH\&WRR) chicken, a total of 25 SNPs were identified in the full length chicken GNPDA2 DNA through PCR sequencing (Table 1). Among these 25 SNPs, 6 SNPs were novel ones, but the other 19 SNPs have already been reported in NCBI SNP database (http://www.ncbi.nlm.nih.gov/snp). According to the transcript cGNPDA2-a, two SNPs were found in the coding sequences, seven SNPs were located in 3' UTR sequences and the other 16 SNPs were located in intron sequences.

The cGNPDA2 SNPs in coding sequences and 3' UTR sequences were genotyped in $\mathrm{F}_{2}$ resource population (XH\&WRR) chicken through PCR sequencing, and then the results were association analysis with productive traits. We found that the two SNPs (g.6667C $>$ T and g.7393C $>$ T) in 3'UTR (Figure 2A) were significantly associated with a number of productive 
217 traits in chicken (Table 2). The genotyped results of these two SNPs were also confirmed by 218 PCR-RFLP (Figure 2B). PCR products of g.6667C $>$ T (1077 bp) and g.7393C $>$ T (648 bp) were 219 digested by Dde I and Ssp I respectively, and then detected enzyme-digested fragments to 220 genotyed the g.6667C $>$ T (TT, 1037 bp; TC, 1077/703/374 bp; CC, 703/374 bp) and g.7393C > T 221 (TT, 648 bp; TC, 648/587/61 bp; CC, 587/61 bp). The g.6667C $>$ T and g.7393C $>$ T 222 (rs14486239) were both significantly associated with body weight during early stage (1-28 days 223 old) of growth (Figure 2C). The g.6667C $>$ T was also significantly associated with chest depth 224 (CD) and abdominal fat pad weight (AFW) (Figure 2D). The g.7393C $>$ T was significantly associated with small intestine length (SIL), leg muscle weight (LMW), dressed weight (DW), eviscerated weight (EW) and semi-eviscerated weight (SEW) (Figure 2D).

227

228

229

230

231

232

233

234

235

236

237

238

239

240

241

242

\subsection{Tissue specific expression of GNPDA2 in XH chicken}

Relative GNPDA2 mRNA expression in different tissues was detected by RT-qPCR and the quantified data are shown in Figure 3. Chicken GNPDA2 gene was expressed in all 17 tested tissues, and there were no significantly different $(P>0.05)$ in expression level of all tissues between female and male chickens (Figure 3). Chicken GNPDA2 gene expression level was highest in abdominal fat, duodenum and hypothalamus, and obvious mRNA expression in subcutaneous fat liver, lung, spleen and pituitary was also detected. However, the low expression level was observed in other tissue, especially in kidney and muscular stomach. In addition, we compared the mRNA level of GNPDA2 in four tissues (abdominal fat, subcutaneous fat, hypothalamus, and liver) of 23 weeks old female $\mathrm{XH}$ chickens with different body weight (high or low body weight). The results showed that GNPDA2 has higher expression in the hypothalamus of high body weight than that in the low body weight chickens (Figure 4A).

\subsection{The effects of dietary status on cGNPDA2 mRNA level}

After feeding chickens with high-glucose-fat diet, the mRNA level of GNPDA2 was increased about 2 -fold in abdominal fat $(P<0.05)$ and subcutaneous fat $(P<0.01)$ than that in the control group (basal diet) of both female and male XH chickens. In liver and hypothalamus, 
243 the mRNA level of GNPDA2 was decreased of both female and male $\mathrm{XH}$ chickens, especially 244 decreased by $38 \%(P<0.05)$ in hypothalamus of female chicken (Figure 4B). In fasted chickens, 245 the mRNA level of GNPDA2 was decreased by $58.8 \%(P<0.05)$ in hypothalamus, and returned 246 to normal level after refeeding. However, no significant difference $(P>0.05)$ was found in 247 adipose tissue and liver among the three experimental groups (control, fasted and re-fed), but the 248 mRNA expression level in abdominal fat and subcutaneous fat tended to be slightly higher $(P>$ 249 0.05) with fasted group (Figure 4C).

The different GNPDA2 genotypes may affect the gene expression levels; this could be a

251

252

253

254

255

256

257

258

259

260

261

262

263

264

265

266

267

268 confounding effect on dietary status. Thus, we performed DNA sequencing to check the genotypes of all 45 chickens used for qPCR experiment (Figure 5A). In 25 female chickens of 23 weeks old, the g.6667C > T have $5 \mathrm{CC}, 12 \mathrm{TC}$ and 8 TT genotypes; the g.7393C $>$ T have $10 \mathrm{CC}, 5$ CT and 10 TT genotypes. We compared the GNPDA2 expression level in these 25 chickens, the results showed that no significant difference were found $(P>0.05)$ among three different genotypes of both g.6667C $>\mathrm{T}$ and g.7393C $>\mathrm{T}$ (Figure $5 \mathrm{~B}$ and C).

\subsection{Overexpression and knockdown of cGNPDA2 in preadipocytes}

In chicken preadipocytes, transfection of recombinant pcDNA3.1(+)-GNPDA2-a led to marked overexpression of $c G N P D A 2(7.32$-fold higher, $P<0.01)$ and siRNA interfering also led to $c G N P D A 2$ decreased by $47 \%(P<0.05)$. With overexpression of $c G N P D A 2$, the mRNA level of $A C C$ (acetyl-CoA carboxylase), FAS (fatty acid synthase), FTO (fat mass and obesityassociated gene) and PGCl $\alpha$ (peroxisome proliferative activated receptor gamma coactivator 1) were up-regulated, and the mRNA level of $A T G L$ (adipose triglyceride lipase), $H L$ (hepatic lipase), PPAR (proxisome proliferator-activated receptor $\gamma$ ), Leptin-R (leptin receptor) and PKM (pyruvate kinase muscle) were down-regulated (Figure 6A). When $c G N P D A 2$ was knockdown, the expression trend of related genes was just contrary to overexpression of $c G N P D A 2$ (Figure 6B). Intriguingly, the mRNA level of $P K M$ was decreased by $32 \%(P<0.05)$ after overexpression $c G N P D A 2$, and increased 1.76-fold $(P<0.05)$ after knockdown $c G N P D A 2$. The 
269

270

271

272

273

274

275

276

277

278

279

280

281

282

283

284

285

286

287

288

289

290

291

292

293

294

expression of PGCla was increased 2.25 -fold $(P<0.05)$ after overexpression $c G N P D A 2$. However, the changes of other related genes statistically were not significant difference after overexpression or knockdown of $c G N P D A 2(P>0.05)$.

\section{Discussion}

GNPDA2 is belongs to GlcN6P subfamily, which encoded an allosteric enzyme of GlcN6P. Many GNPDA2 transcripts were previously characterized in mammals, such as human, mouse and pig (Leloir \& Cardini, 1956; Arreola et al., 2003; Li et al., 2010). Four novel chicken GNPDA2 transcripts (cGNPDA2-a $\sim$ GNPDA2-d) were identified in this study. The predominant transcript GNPDA2-a has conserved domain of GlcN6P and share $85.5 \%$ amino acid identity with the other chicken GlcN6P (GNPDA1). This result is similar to that reported in human GNPDA2, which also share $87 \%$ amino acid identity with human GNPDA1 (Arreola et al., 2003). Other chicken GNPDA2 transcripts encode different short peptide, and did not contain the domain of GlcN6P. GNPDA2 was reported to be conserved in mammalians (Arreola et al., 2003), here, we also used nucleotide BLAST analysis to detect homology between the amino acid sequence of GNPDA2 among 18 species, and the result showed that GNPDA2 was highly conserve among vertebrates, especially in birds.

The genomic structure of chicken GNPDA2 is similar with human and mouse; they both comprised seven exons and six introns. The chicken GNPDA2 gene spanned over $7 \mathrm{~Kb}$ in length and has many variations. Gene variations might have significant effects on animal biology function. Previous studies showed that SNPs of human GNPDA2 gene were associated with both BMI and body weight (Willer et al., 2009). Thus, we detected mutations of $c$ GNPDA2 and performed an association analysis with chicken production traits in our $\mathrm{F}_{2}$ resource population. The results also showed that two of $c G N P D A 2$ SNPs were associated with chicken body weight and fatness traits.

GNPDA2 gene expressed ubiquitously in mammalians (Arreola et al., 2003; Skarnes et al., 2011; Graff et al., 2013), and was found to be highly expressed in hypothalamus of rat (Schmid 
295

296

297

298

299

300

301

302

303

304

305

306

307

308

309

310

311

312

313

314

315

316

317

318

319

320

321

et al., 2012). In the present study, we found GNPDA2 gene expressed in 17 various tissues of both male and female chicken. It also predominantly expressed in hypothalamus, duodenum and adipose tissues (subcutaneous fat and abdominal fat), and the expression level were not significantly different between female and male chickens. GNPDA2 gene plays an important role in hexosamine signaling pathway, which is one of the main nutrient-sensing pathways in organisms (Marshall, 2006; Oikari et al., 2016). GNPDA2 may be regulated in response to nutrition status or by dietary components. Previously study reported that the mRNA level of GNPDA2 was down-regulated in the hypothalamus of rats fed with high fat diet (Ruth et al., 2011). In this study, we detected the change of GNPDA2 expression with high-glucose-fat diet and fasted/refed conditions in hypothalamus, adipose tissue and liver when compared with controls (basal diet). The results showed that the expression of chicken GNPDA2 gene was change by different dietary status. Different genotypes of GNPDA2 gene also may changes the gene expression. Therefore, we detected the genotype of these chickens and compared the GNPDA2 expression level, the results showed that no significant difference were found among three different genotypes of both g.6667C $>\mathrm{T}$ and g.7393C $>\mathrm{T}$. These results confirmed that the expression of GNPDA2 was regulated by both feeding/fasting and by consumption of the highglucose-fat diet and suggests a role of GNPDA2 gene in fat and energy metabolism in chicken.

The regulation of fat metabolism, especially the function of GNPDA2 in chicken preadipocytes (lipogenesis) is not yet clearly understood. We have found that variations of $c G N P D A 2$ were associated with chicken body weight and fatness traits. To further identify the functions of GNPDA2, we performed overexpression and siRNA interfering of GNPDA2 in preadipocytes, and detected the change of fat and energy metabolism related genes. The results showed that the effects of GNPDA2 on fat metabolism related gene were minor and are not significant $(P>0.05)$, such as fat synthesis gene $(A C C$ and $F A S)$, lipolysis gene $(A T G L$ and $H L)$, and preadipocytes differentiation gene $(P P A R \gamma)$. However, $P G C 1 \alpha$, a key transcriptional coactivator of energy metabolism, was increased after overexpression of GNPDA2 (Espinoza \& Patti, 2005; Schuler et al., 2006). PMK was down-regulated by GNPDA2, which plays a crucial 
322 role on glucose and energy metabolism (Yang, 2015). These results suggest that GNPDA2 might

323 regulate energy metabolism through $P G C 1 \alpha$ and $P M K$, but the clear role of chicken GNPDA2 in

324 the regulation of fat and energy metabolism pathway still needs further study.

\section{Conclusions}

326 In conclusion, herein we identified four novel chicken GNPDA2 transcripts. The chicken 327 GNPDA2 gene was predominantly expressed in hypothalamus and adipose tissues. Its expression 328 was regulated by both feeding/fasting and by consumption of the high-glucose-fat diet as 329 compared with that of the controls. Overexpression of GNPDA2 in chicken preadipocytes 330 promoted the expression of $P G C 1 \alpha$ but inhibited PKM. Two SNPs of $c G N P D A 2$ gene were 331 found to be markedly associated with body weight and fatness traits in chicken. Our data suggest 332 that the GNPDA2 gene is related to body weight, fat and energy metabolism in chicken.

\section{Acknowledgements}

335 We thank the chicken farm workers of SCAU for their assistance in animal raising. 


\section{References}

Arreola R, Valderrama B, Morante ML, Horjales E. 2003. Two mammalian glucosamine-6phosphate deaminases: a structural and genetic study. FEBS Lett 551: 63-70 DOI 10.1016/S0014-5793(03)00896-2.Barsh GS, Farooqi IS, O’Rahilly S. 2000. Genetics of body-weight regulation. Nature 404: 644-651.

Boekholt H, Van Der Grinten P, Schreurs V, Los M, Leffering CP. 1994. Effect of dietary energy restriction on retention of protein, fat and energy in broiler chickens. Br Poult Sci 35: 603-614 DOI 10.1080/00071669408417725.

Castellini C, Mugnai C, and Dal Bosco A. 2002. Effect of organic production systern on broiler carcass and meat quality. Meat Sci 60: 219-225 DOI 10.1016/S0309-1740(01)00124-3.

Elks CE, Loos RJ, Sharp SJ, Langenberg C, Ring SM, Timpson NJ, Ness AR, Davey Smith G, Dunger DB, Wareham NJ, Ong KK. 2010. Genetic markers of adult obesity risk are associated with greater early infancy weight gain and growth. PLoS Med 7: e1000284 DOI 10.1371/journal.pmed.1000284.

Espinoza DO, Patti ME. 2005. PGC1 expression alters lipid metabolism and partitioning in skeletal muscle cells: potential links to insulin resistance susceptibility. Diabetes 54: A360.

Finkelstein EA, Trogdon JG, Brown DS, Allaire BT, Dellea PS, Kamal-Bahl SJ. 2008. The lifetime medical cost burden of overweight and obesity: implications for obesity prevention. Obesity 16: 1843-1848 DOI 10.1038/oby.2008.290.

Flegal KM, Graubard BI, Williamson DF, Gail MH. 2007. Cause-specific excess deaths associated with underweight, overweight, and obesity. J. Am. Med. Assoc. 298:2028-2037 DOI 10.1001/jama.298.17.2028.

Gong J, Schumacher F, Lim U, Hindorff LA, Haessler J, Buyske S, Carlson CS, Rosse S, Bůžková P, Fornage M, Gross M, Pankratz N, Pankow JS, Schreiner PJ, Cooper R, Ehret G, Gu CC, Houston D, Irvin MR, Jackson R, Kuller L, Henderson B, Cheng I, Wilkens L, Leppert M, Lewis CE, Li R, Nguyen KD, Goodloe R, Farber-Eger E, Boston J, Dilks HH, Ritchie MD, Fowke J, Pooler L, Graff M, Fernandez-Rhodes L, Cochrane B, Boerwinkle E, 
364

365

366

367

368

369

370

371

372

373

374

375

376

377

378

379

380

381

382

383

384

385

386

387

388

389

Kooperberg C, Matise TC, Le Marchand L, Crawford DC, Haiman CA, North KE, Peters U. 2013. Fine Mapping and Identification of BMI Loci in African Americans. Am J Hum Genet 93: 661-671 DOI 10.1016/j.ajhg.2013.08.012.

Graff M, Ngwa JS, Workalemahu T, Homuth G, Schipf S, Teumer A, Völzke H, Wallaschofski H, Abecasis GR, Edward L, Francesco C, Sanna S, Scheet P, Schlessinger D, Sidore C, Xiao X, Wang Z, Chanock SJ, Jacobs KB, Hayes RB, Hu F, Van Dam RM; GIANT Consortium, Crout RJ, Marazita ML, Shaffer JR, Atwood LD, Fox CS, Heard-Costa NL, White C, Choh AC, Czerwinski SA, Demerath EW, Dyer TD, Towne B, Amin N, Oostra BA, Van Duijn CM, Zillikens MC, Esko T, Nelis M, Nikopensius T, Metspalu A, Strachan DP, Monda K, Qi L, North KE, Cupples LA, Gordon-Larsen P, Berndt SI. 2013. Genomewide analysis of BMI in adolescents and young adults reveals additional insight into the effects of genetic loci over the life course. Hum Mol Genet 22:3597-607 DOI $10.1093 / \mathrm{hmg} / \mathrm{ddt} 205$.

Hotta K, Nakamura M, Nakamura T, Matsuo T, Nakata Y, Kamohara S, Miyatake N, Kotani K, Komatsu R, Itoh N, Mineo I, Wada J, Masuzaki H, Yoneda M, Nakajima A, Funahashi T, Miyazaki S, Tokunaga K, Kawamoto M, Ueno T, Hamaguchi K, Tanaka K, Yamada K, Hanafusa T, Oikawa S, Yoshimatsu H, Nakao K, Sakata T, Matsuzawa Y, Kamatani N, Nakamura Y. 2009. Association between obesity and polymorphisms in SEC16B, TMEM18, GNPDA2, BDNF, FAIM2 and MC4R in a Japanese population. J Hum Genet 54: 727-31 DOI 10.1038/jhg.2009.106.

Kong X, Zhang X, Xing X, Zhang B, Hong J, Yang W. 2015. The Association of Type 2 Diabetes Loci Identified in Genome-Wide Association Studies with Metabolic Syndrome and Its Components in a Chinese Population with Type 2 Diabetes. PLoS One 10: e0143607 DOI 10.1371/journal.pone.0143607.

Kopelman PG. 2000. Obesity as a medical problem. Nature 404: 635-643 DOI $10.1038 / 35007508$. 
390

391

392

393

394

395

396

397

398

399

400

401

402

403

404

405

406

407

408

409

410

411

412

413

414

415

416
Lei MM, Nie QH, Peng X, Zhang DX, Zhang XQ. 2005. Single nucleotide polymorphisms of the chicken insulin-like factor binding protein 2 gene associated with chicken growth and carcass traits. Poult Sci 84:1191-1198.

Leloir LF, Cardini CE. 1956. Enzymes acting on glucosamine phosphate. Biochim Biophys Acta 20: 33-42 DOI 10.1016/0006-3002(56)90259-1.

Li S, Zhao JH, Luan J, Luben RN, Rodwell SA, Khaw KT, Ong KK, Wareham NJ, Loos RJ. 2010. Cumulative effects and predictive value of common obesity-susceptibility variants identified by genome-wide association studies. Am J Clin Nutr 91:184-190 DOI 10.3945/ajen.2009.28403.

Maes HH, Neale MC, Eaves LJ. 1997. Genetic and environmental factors in relative body weight and human adiposity. Behav Genet 27: 325-35 DOI 10.1023/A:1025635913927.

Marshall S. 2006. Role of insulin, adipocyte hormones, and nutrient-sensing pathways in regulating fuel metabolism and energy homeostasis: a nutritional perspective of diabetes, obesity, and cancer. Sci STKE 2006:re7 DOI 10.1126/stke.3462006re7.

Mejía-Benítez A, Klünder-Klünder M, Yengo L, Meyre D, Aradillas C, Cruz E, Pérez-Luque E, Malacara JM, Garay ME, Peralta-Romero J, Flores-Huerta S, García-Mena J, Froguel P, Cruz M, Bonnefond A. 2013. Analysis of the contribution of FTO, NPC1, ENPP1, NEGR1, GNPDA2 and MC4R genes to obesity in Mexican children. BMC Med Genet 14: 21 DOI 10.1186/1471 -2350-14-21.

Murphy RA, Nalls MA, Keller M, Garcia M, Kritchevsky SB, Tylavsky FA, Newman AB, Tranah GJ, Eiriksdottir G, Gudnason V, Harris TB. 2013. Candidate Gene Association Study of BMI-Related Loci, Weight, and Adiposity in Old Age. J Gerontol A Biol Sci Med Sci 68: 661-666 DOI 10.1093/gerona/gls227.

Oikari S, Makkonen K, Jawahar Deen A, Tyni I, Kärnä R, Tammi RH, Tammi MI. 2016. Hexosamine biosynthesis in keratinocytes - roles of GFAT and GNPDA enzymes in the maintenance of UDP-GlcNAc content and hyaluronan synthesis. Glycobiology pii: cww019 [Epub ahead of print]. 
417 Petracci M, Sirri F, Mazzoni M, Meluzzi A. 2013. Comparison of breast muscle traits and meat 418 quality characteristics in 2 commercial chicken hybrids. Poult Sci 92: 2438-47 DOI 419 10.3382/ps.2013-03087.Pillay V, Crowther NJ, Ramsay M, Smith GD, Norris SA, Lombard 420 Z. 2015. Exploring genetic markers of adult obesity risk in black adolescent South Africans-the Birth to Twenty Cohort. Nutrition \& Diabetes 5: e157 DOI 10.1038/nutd.2015.7.

Ramsay TG, Rosebrough RW. 2003. Hormonal regulation of postnatal chicken preadipocyte differentiation in vitro. Comp Biochem Physiol B Biochem Mol Biol 136:245-253 DOI 10.1016/S1096-4959(02)00261-0.

Robiou-du-Pont S, Bonnefond A, Yengo L, Vaillant E, Lobbens S, Durand E, Weill J, Lantieri O, Balkau B, Charpentier G, Marre M, Froguel P, Meyre D. 2013. Contribution of 24 obesity-associated genetic variants to insulin resistance, pancreatic beta-cell function and type 2 diabetes risk in the French population. Int $J$ Obes (Lond) 37: 980-985 DOI 10.1038/ijo.2012.175.

Ruth GA, Kim DH, Woods SC, Seeley RJ. 2011. Expression of New Loci associated With Obesity in Diet-Induced Obese Rats: from Genetics to Physiology. Obesity 20: 306-312 DOI 10.1038/oby.2011.236.

Schmid PM, Heid I, Buechler C, Steege A, Resch M, Birner C, Endemann DH, Riegger GA, Luchner A. 2012. Expression of fourteen novel obesityrelated genes in zucker diabetic fatty rats. Cardiovascular Diabetology 11:48 DOI 10.1186/1475-2840-11-48.

Schuler M, Ali F, Chambon C, Duteil D, Bornert JM, Tardivel A, Desvergne B, Wahli W, Chambon P, Metzger D. 2006. PGC1 alphaexpression is controlled in skeletal muscles by PPAR beta, whose ablation results in fiber-type switching, obesity, and type 2 diabetes. Cell Metab 4: 407-414 DOI 10.1016/j.cmet.2006.10.003.

Skarnes WC, Rosen B, West AP, Koutsourakis M, Bushell W, Iyer V, Mujica AO, Thomas M, Harrow J, Cox T, Jackson D, Severin J, Biggs P, Fu J, Nefedov M, de Jong PJ, Stewart AF, 
443

444

445

446

447

448

449

450

451

452

453

454

455

456

457

458

459

460

461

462

463

464

465

466

467

468

469

Bradley A. 2011. A conditional knockout resource for the genome-wide study of mouse gene function. Nature 474: 337-42 DOI 10.1038/nature10163.

Speliotes EK, Willer CJ, Berndt SI, Monda KL, Thorleifsson G, Jackson AU, Lango Allen H, Lindgren CM, Luan J, Mägi R, Randall JC, Vedantam S, Winkler TW, Qi L, Workalemahu T, Heid IM, Steinthorsdottir V, Stringham HM, Weedon MN, Wheeler E, Wood AR, Ferreira T, Weyant RJ, Segrè AV, Estrada K, Liang L, Nemesh J, Park JH, Gustafsson S, Kilpeläinen TO, Yang J, Bouatia-Naji N, Esko T, Feitosa MF, Kutalik Z, Mangino M, Raychaudhuri S, Scherag A, Smith AV, Welch R, Zhao JH, Aben KK, Absher DM, Amin N, Dixon AL, Fisher E, Glazer NL, Goddard ME, Heard-Costa NL, Hoesel V, Hottenga JJ, Johansson A, Johnson T, Ketkar S, Lamina C, Li S, Moffatt MF, Myers RH, Narisu N, Perry JR, Peters MJ, Preuss M, Ripatti S, Rivadeneira F, Sandholt C, Scott LJ, Timpson NJ, Tyrer JP, van Wingerden S, Watanabe RM, White CC, Wiklund F, Barlassina C, Chasman DI, Cooper MN, Jansson JO, Lawrence RW, Pellikka N, Prokopenko I, Shi J, Thiering E, Alavere H, Alibrandi MT, Almgren P, Arnold AM, Aspelund T, Atwood LD, Balkau B, Balmforth AJ, Bennett AJ, Ben-Shlomo Y, Bergman RN, Bergmann S, Biebermann H, Blakemore AI, Boes T, Bonnycastle LL, Bornstein SR, Brown MJ, Buchanan TA, Busonero F, Campbell H, Cappuccio FP, Cavalcanti-Proença C, Chen YD, Chen CM, Chines PS, Clarke R, Coin L, Connell J, Day IN, den Heijer M, Duan J, Ebrahim S, Elliott P, Elosua R, Eiriksdottir G, Erdos MR, Eriksson JG, Facheris MF, Felix SB, Fischer-Posovszky P, Folsom AR, Friedrich N, Freimer NB, Fu M, Gaget S, Gejman PV, Geus EJ, Gieger C, Gjesing AP, Goel A, Goyette P, Grallert H, Grässler J, Greenawalt DM, Groves CJ, Gudnason V, Guiducci C, Hartikainen AL, Hassanali N, Hall AS, Havulinna AS, Hayward C, Heath AC, Hengstenberg C, Hicks AA, Hinney A, Hofman A, Homuth G, Hui J, Igl W, Iribarren C, Isomaa B, Jacobs KB, Jarick I, Jewell E, John U, Jørgensen T, Jousilahti P, Jula A, Kaakinen M, Kajantie E, Kaplan LM, Kathiresan S, Kettunen J, Kinnunen L, Knowles JW, Kolcic I, König IR, Koskinen S, Kovacs P, Kuusisto J, Kraft P, Kvaløy K, Laitinen J, Lantieri O, Lanzani C, Launer LJ, Lecoeur C, Lehtimäki T, Lettre G, Liu J, Lokki ML, 
470

471

472

473

474

475

476

477

478

479

480

481

482

483

484

485

486

487

488

489

490

491

492

493

494

495

496

Lorentzon M, Luben RN, Ludwig B; MAGIC, Manunta P, Marek D, Marre M, Martin NG, McArdle WL, McCarthy A, McKnight B, Meitinger T, Melander O, Meyre D, Midthjell K, Montgomery GW, Morken MA, Morris AP, Mulic R, Ngwa JS, Nelis M, Neville MJ, Nyholt DR, O'Donnell CJ, O'Rahilly S, Ong KK, Oostra B, Paré G, Parker AN, Perola M, Pichler I, Pietiläinen KH, Platou CG, Polasek O, Pouta A, Rafelt S, Raitakari O, Rayner NW, Ridderstråle M, Rief W, Ruokonen A, Robertson NR, Rzehak P, Salomaa V, Sanders AR, Sandhu MS, Sanna S, Saramies J, Savolainen MJ, Scherag S, Schipf S, Schreiber S, Schunkert H, Silander K, Sinisalo J, Siscovick DS, Smit JH, Soranzo N, Sovio U, Stephens J, Surakka I, Swift AJ, Tammesoo ML, Tardif JC, Teder-Laving M, Teslovich TM, Thompson JR, Thomson B, Tönjes A, Tuomi T, van Meurs JB, van Ommen GJ, Vatin V, Viikari J, Visvikis-Siest S, Vitart V, Vogel CI, Voight BF, Waite LL, Wallaschofski H, Walters GB, Widen E, Wiegand S, Wild SH, Willemsen G, Witte DR, Witteman JC, Xu J, Zhang Q, Zgaga L, Ziegler A, Zitting P, Beilby JP, Farooqi IS, Hebebrand J, Huikuri HV, James AL, Kähönen M, Levinson DF, Macciardi F, Nieminen MS, Ohlsson C, Palmer LJ, Ridker PM, Stumvoll M, Beckmann JS, Boeing H, Boerwinkle E, Boomsma DI, Caulfield MJ, Chanock SJ, Collins FS, Cupples LA, Smith GD, Erdmann J, Froguel P, Grönberg H, Gyllensten U, Hall P, Hansen T, Harris TB, Hattersley AT, Hayes RB, Heinrich J, Hu FB, Hveem K, Illig T, Jarvelin MR, Kaprio J, Karpe F, Khaw KT, Kiemeney LA, Krude H, Laakso M, Lawlor DA, Metspalu A, Munroe PB, Ouwehand WH, Pedersen O, Penninx BW, Peters A, Pramstaller PP, Quertermous T, Reinehr T, Rissanen A, Rudan I, Samani NJ, Schwarz PE, Shuldiner AR, Spector TD, Tuomilehto J, Uda M, Uitterlinden A, Valle TT, Wabitsch M, Waeber G, Wareham NJ, Watkins H; Procardis Consortium, Wilson JF, Wright AF, Zillikens MC, Chatterjee N, McCarroll SA, Purcell S, Schadt EE, Visscher PM, Assimes TL, Borecki IB, Deloukas P, Fox CS, Groop LC, Haritunians T, Hunter DJ, Kaplan RC, Mohlke KL, O'Connell JR, Peltonen L, Schlessinger D, Strachan DP, van Duijn CM, Wichmann HE, Frayling TM, Thorsteinsdottir U, Abecasis GR, Barroso I, Boehnke M, Stefansson K, North KE, McCarthy MI, Hirschhorn JN, Ingelsson E, Loos RJ. 2010. 
497

498

499

500

501

502

503

504

505

506

507

508

509

510

511

512

513

514

515

516

517

518

519

520

521

522

523

Association analyses of 249,796 individuals reveal 18 new loci associated with body mass index. Nat Genet 42: 937-948 DOI 10.1038/ng.686.

Takeuchi F, Yamamoto K, Katsuya T, Nabika T, Sugiyama T, Fujioka A, Isono M, Ohnaka K, Fujisawa T, Nakashima E, Ikegami H, Nakamura J, Yamori Y, Yamaguchi S, Kobayashi S, Ogihara T, Takayanagi R, Kato N. 2011. Association of genetic variants for susceptibility to obesity with type 2 diabetes in Japanese individuals. Diabetologia 54: 1350-1359 DOI 10.1007/s00125-011-2086-8.

Tomei S, Mamtani R, Al Ali R, Elkum N, Abdulmalik M, Ismail A, Cheema S, Rouh HA, Aigha II, Hani F, Al-Samraye S, Taher Aseel M, El Emadi N, Al Mujalli A, Abdelkerim A, Youssif S, Worschech A, El Sebakhy E, Temanni R, Khanna V, Wang E, Kizhakayil D, AlThani AA, Al-Thani M, Lowenfels A, Marincola FM, Sheikh J, Chouchane L. 2015. Obesity susceptibility loci in Qataris, a highly consanguineous Arabian population. Journal of Translational Medicine 13: (1) DOI 10.1186/s12967-015-0459-3.

Wen W, Cho YS, Zheng W, Dorajoo R, Kato N, Qi L, Chen CH, Delahanty RJ, Okada Y, Tabara Y, Gu D, Zhu D, Haiman CA, Mo Z, Gao YT, Saw SM, Go MJ, Takeuchi F, Chang LC, Kokubo Y, Liang J, Hao M, Le Marchand L, Zhang Y, Hu Y, Wong TY, Long J, Han BG, Kubo M, Yamamoto K, Su MH, Miki T, Henderson BE, Song H, Tan A, He J, Ng DP, Cai Q, Tsunoda T, Tsai FJ, Iwai N, Chen GK, Shi J, Xu J, Sim X, Xiang YB, Maeda S, Ong RT, Li C, Nakamura Y, Aung T, Kamatani N, Liu JJ, Lu W, Yokota M, Seielstad M, Fann CS, Wu JY, Lee JY, Hu FB, Tanaka T, Tai ES, Shu XO. 2012. Meta-analysis identifies common variants associated with body mass index in east Asians. Nat Genet 44: 307-311 DOI 10.1038/ng.1087.

Willer CJ, Speliotes EK, Loos RJ, Li S, Lindgren CM, Heid IM, Berndt SI, Elliott AL, Jackson AU, Lamina C, Lettre G, Lim N, Lyon HN, McCarroll SA, Papadakis K, Qi L, Randall JC, Roccasecca RM, Sanna S, Scheet P, Weedon MN, Wheeler E, Zhao JH, Jacobs LC, Prokopenko I, Soranzo N, Tanaka T, Timpson NJ, Almgren P, Bennett A, Bergman RN, Bingham SA, Bonnycastle LL, Brown M, Burtt NP, Chines P, Coin L, Collins FS, Connell 
524

525

526

527

528

529

530

531

532

533

534

535

536

537

538

539

540

541

542

543

544

545

546

547

548

549

550

JM, Cooper C, Smith GD, Dennison EM, Deodhar P, Elliott P, Erdos MR, Estrada K, Evans DM, Gianniny L, Gieger C, Gillson CJ, Guiducci C, Hackett R, Hadley D, Hall AS, Havulinna AS, Hebebrand J, Hofman A, Isomaa B, Jacobs KB, Johnson T, Jousilahti P, Jovanovic Z, Khaw KT, Kraft P, Kuokkanen M, Kuusisto J, Laitinen J, Lakatta EG, Luan J, Luben RN, Mangino M, McArdle WL, Meitinger T, Mulas A, Munroe PB, Narisu N, Ness AR, Northstone K, O'Rahilly S, Purmann C, Rees MG, Ridderstråle M, Ring SM, Rivadeneira F, Ruokonen A, Sandhu MS, Saramies J, Scott LJ, Scuteri A, Silander K, Sims MA, Song K, Stephens J, Stevens S, Stringham HM, Tung YC, Valle TT, Van Duijn CM, Vimaleswaran KS, Vollenweider P, Waeber G, Wallace C, Watanabe RM, Waterworth DM, Watkins N; Wellcome Trust Case Control Consortium, Witteman JC, Zeggini E, Zhai G, Zillikens MC, Altshuler D, Caulfield MJ, Chanock SJ, Farooqi IS, Ferrucci L, Guralnik JM, Hattersley AT, Hu FB, Jarvelin MR, Laakso M, Mooser V, Ong KK, Ouwehand WH, Salomaa V, Samani NJ, Spector TD, Tuomi T, Tuomilehto J, Uda M, Uitterlinden AG, Wareham NJ, Deloukas P, Frayling TM, Groop LC, Hayes RB, Hunter DJ, Mohlke KL, Peltonen L, Schlessinger D, Strachan DP, Wichmann HE, McCarthy MI, Boehnke M, Barroso I, Abecasis GR, Hirschhorn JN. 2009. Six new loci associated with body mass index highlight a neuronal influence on body weight regulation. Nat Genet 41: 25-34 DOI 10.1038/ng.287.

Xi B, Cheng H, Shen Y, Chandak GR, Zhao X, Hou D, Wu L, Wang X, Mi J. 2013. Study of 11 BMI-associated loci identified in GWAS for associations with central obesity in the Chinese children. PLoS One 8: e56472 DOI 10.1371/journal.pone.0056472.

Xi B, Zhao X, Shen Y, Wu L, Hotta K, Hou D, Cheng H, Wang X, Mi J. 2013. Associations of obesity susceptibility loci with hypertension in Chinese children. Int J Obes (Lond) 37: 92630 DOI 10.1038/ijo.2013.37.

Xi B, Zhao X, Shen Y, Wu L, Hou D, Cheng H, Mi J. 2014. An obesity genetic risk score predicts risk of insulin resistance among Chinese children. Endocrine 47: 825-832 DOI 10.1007/s12020-014-0217-y. 
551 Yang W. 2015. Structural basis of PKM2 regulation. Protein Cell 6: 238-40 DOI $552 \quad 10.1007 / \mathrm{s} 13238-015-0146-4$.

553 Zerehdaran S, Vereijken A, Van Arendonk J, Van der Waaijt EH. 2004. Estimation of genetic 554 parameters for fat deposition and carcass traits in broilers. Poult Sci 83: 521-525. 
Figure 1 (on next page)

Characterization of four chicken GNPDA2 variant transcripts.

(A) Genomic structure of chicken GNPDA2. UTR, untranslated region; ORF, open reading frame. (B) The open reading frame of four CGNPDA2 variant transcripts. The letter atg with shadow is initiation codon, and the letter taa or tga with underline is termination codon. 


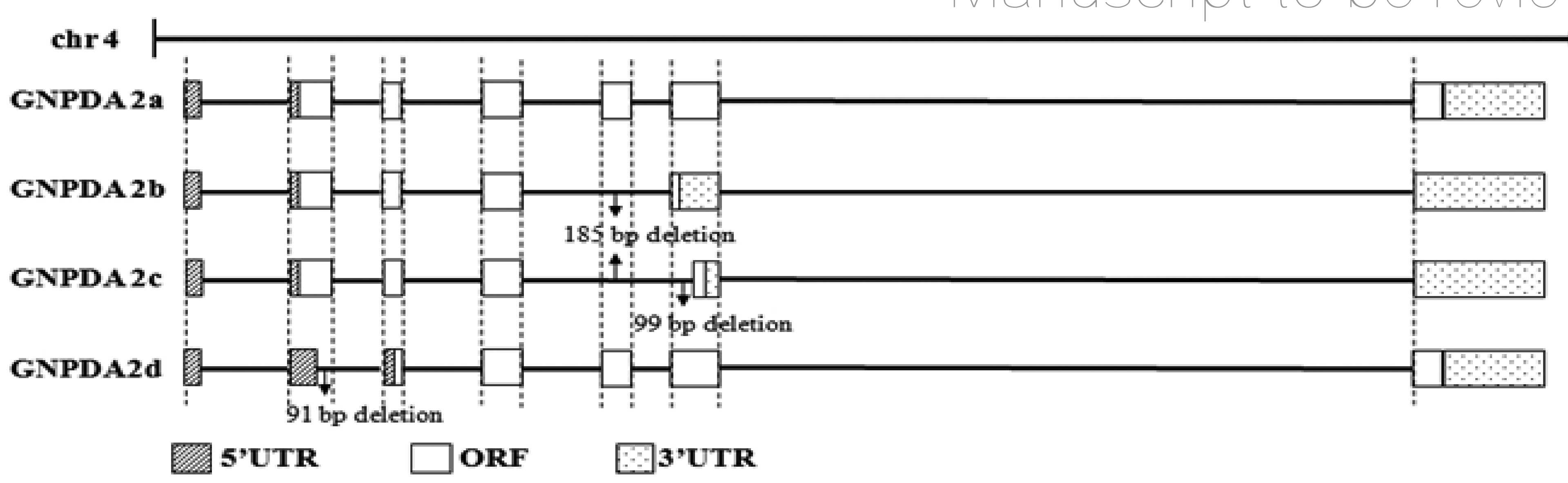

\section{A}

1 atgaggcttgtcat tct tgaagac tacga tcaggcaag tgaatgggcagccaaatacatctgcaatcg tat ta tccaat tcaagcc tact

$\begin{array}{lllllllllllllllllllllllllllllll}M & \mathbb{R} & \mathrm{L} & \mathrm{V} & \mathrm{I} & \mathrm{L} & \mathrm{E} & \mathrm{D} & \mathrm{Y} & \mathrm{D} & \mathrm{Q} & \mathrm{A} & \mathrm{S} & \mathrm{E} & \mathrm{W} & \mathrm{A} & \mathrm{A} & \mathrm{K} & \mathrm{Y} & \mathrm{I} & \mathrm{C} & \mathrm{N} & \mathrm{R} & \mathrm{I} & \mathrm{I} & \mathrm{Q} & \mathrm{F} & \mathbb{K} & \mathrm{P} & \mathrm{T}\end{array}$ $\begin{array}{lllllllllllllllllllllllllllllll}M & R & L & V & I & L & E & D & Y & D & Q & A & S & E & W & A & A & K & Y & I & C & N & R & I & I & Q & F & K & P & T\end{array}$

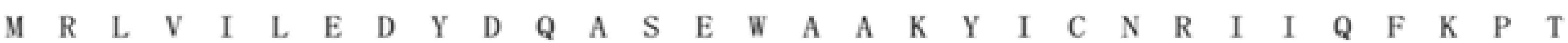

GNPDA2-a

GNPDA2-b

caaggaagatact tcacact tgg tctaccgacagggagtacaccat tgggctgctacaaaaagctaatagaatatcacaagaatggagat

$\begin{array}{llllllllllllllllllllllllllllllllllll}\text { Q } & G & \text { R } & \text { Y } & \text { F } & \text { T } & \text { L } & \text { G } & \text { L } & \text { P } & \text { T } & \text { G } & \text { S } & \text { T } & \text { P } & \text { L } & \text { G } & \text { C } & \text { Y } & \text { K } & \text { K } & \text { L } & \text { I } & \text { E } & \text { Y } & \text { H } & \text { K } & \text { N } & \text { G } & \text { D }\end{array}$

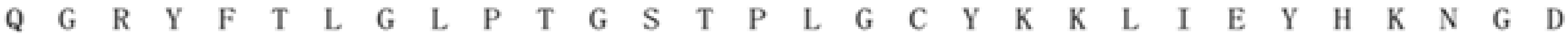

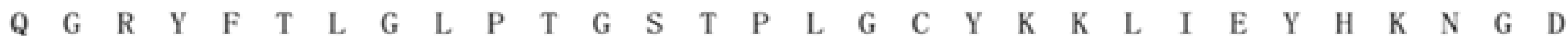

181 ctctcttcaaatatgtgaagactt tcaacatggatgaatatgt tggacttcccagaaatcatccagagagt ta tcat tca tatatgtgg

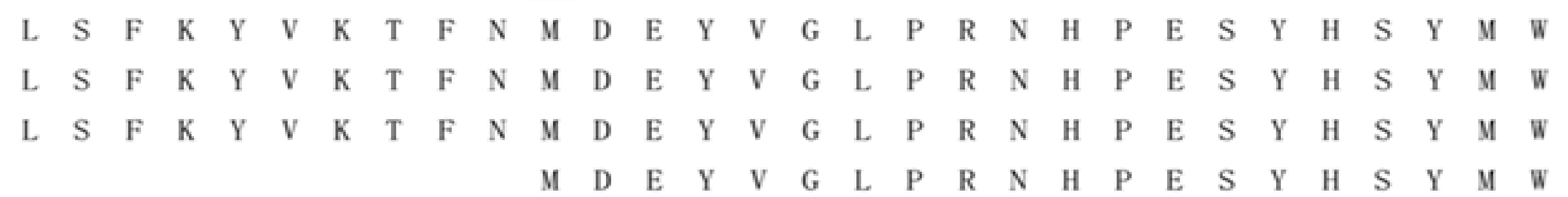

GNPDA2-c

GNPDA2-a

GNPDA2-b

GNPDA2-c

GNPDA2-a

GNPDA2-b

GNPDA2-c

GNPDA2-d

271 aataact tctttaaacatat gacatagatccaaataatgctcatatccttgatgggaatgctccagact tacaggtggaatgtgatgca

$\begin{array}{llllllllllllllllllllllllllllllll}\mathrm{N} & \mathrm{N} & \mathrm{F} & \mathrm{F} & \mathrm{K} & \mathrm{H} & \mathrm{I} & \mathrm{D} & \mathrm{I} & \mathrm{D} & \mathrm{P} & \mathrm{N} & \mathrm{N} & \mathrm{A} & \mathrm{H} & \mathrm{I} & \mathrm{L} & \mathrm{D} & \mathrm{G} & \mathrm{N} & \mathrm{A} & \mathrm{P} & \mathrm{D} & \mathrm{L} & \mathrm{Q} & \mathrm{V} & \mathrm{E} & \mathrm{C} & \mathrm{D} & \mathrm{A}\end{array}$

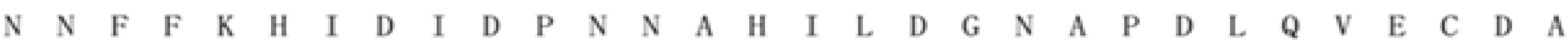

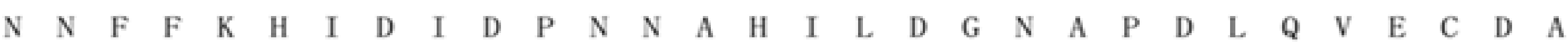

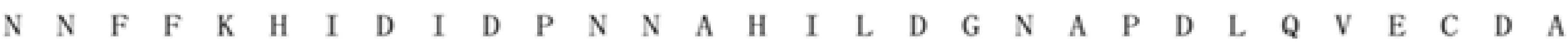

361 tttgaaaagaaaat tgaagaagcaggagggattgatctgtttgttggaggcattggtccagatggccacattgcattcaatgaacccgga

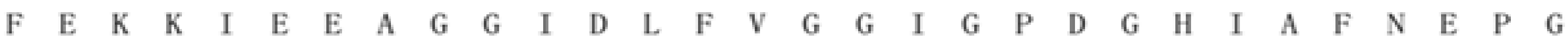

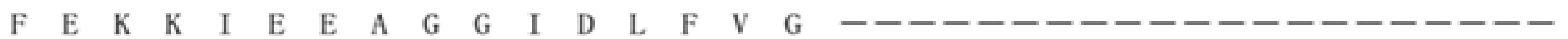

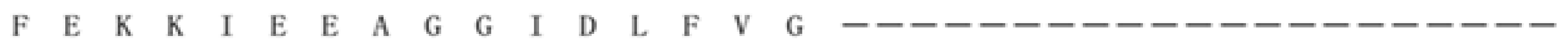

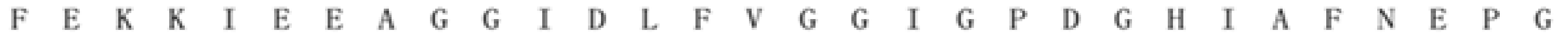

GNPDA2-a GNPDA2-b GNPDA2- c GNPDA2- d

GNPDA2-a

GNPDA2- b

GNPDA2- $\mathrm{c}$

GNPDA2- d

451 tcgagtttgtct tcaagaacaagattaaagacttagcaatggacaccattt tggcaaatgctaaatacttgatggagacttatctaaa

$\begin{array}{lllllllllllllllllllllllllllllllll}S & S & L & S & S & R & T & R & L & K & T & L & A & M & D & T & I & L & A & N & A & K & Y & F & D & G & D & L & S & K\end{array}$

GNPDA2-a

GNPDA2- b

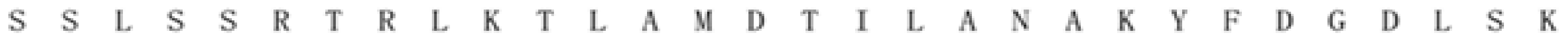

GNPDA2- c

GNPDA2- $\mathrm{d}$

541 gtaccaactatggcgc taacggttggtgtgggtacag tgatggatgctagagaagtgatgat tct tataacagg tgcacataaagcttt

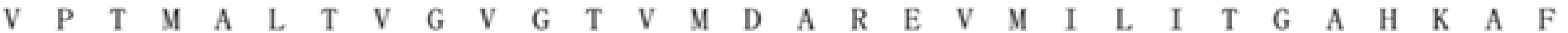

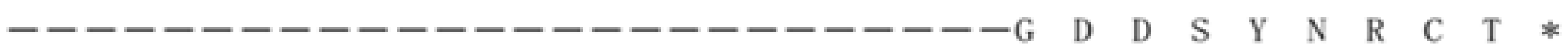

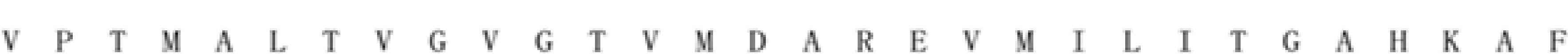

631 gcat tatacaaagctattgaagaaggtgtcaatcatatgtggacagtt tctgctt tccagcagcaccotcgtac tatct tcgtgtgtgat

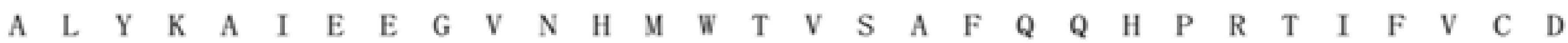

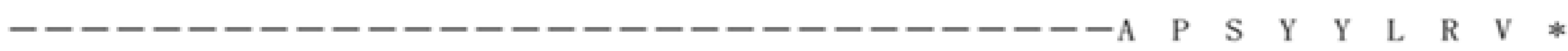

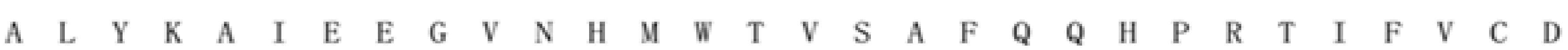

721 gaagatgctact tagaactaagagtcaaaactgtgaagtact taaaggtt taatgcatgtgcacaataaactcgtggacccactgtac

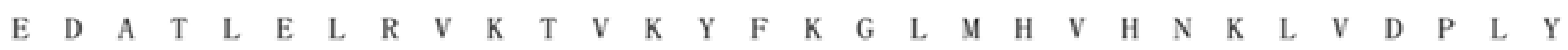

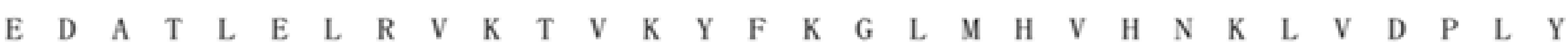
811 agtatgaaagaaaactga 828

$\begin{array}{llllll}\mathrm{S} & \mathrm{M} & \mathrm{K} & \mathrm{E} & \mathrm{N} & *\end{array}$

$\mathrm{S} \quad \mathrm{M} \quad \mathrm{K} \quad \mathrm{E} \quad \mathrm{N}$ *

Peer] reviewing PDF | (2016:02:9369:1:0:NEW 13 May 2016)
GNPDA2-a

GNPDA2- b

GNPDA2- c

GNPDA2-

GNPDA2-a GNPDA2-c GNPDA2- d

GNPDA2-a

GNPDA2- d

GNPDA2-a

GNPDA2- d 
Figure 2 (on next page)

Two SNPs of cGNPDA2 gene associated with body weight and fatness traits in chicken.

(A) The sequencing profiles of the two SNPs in CGNPDA2 gene. $R$ and $Y$ are heterozygous, in which $R=A / G$ and $Y=C / T$. (B) Agarose gel results of two SNPs genotyped by PCR-RFLP. M, DNA marker; $T$, TC and $C C$ are three different genotypes. (C) The association of the two SNPs with the body weight of chickens during early stage of growth. (D) The association of the two SNPs with the fatness traits of chickens. DW, dressed weight; EW, eviscerated weight; SEW, semi-eviscerated weight. 


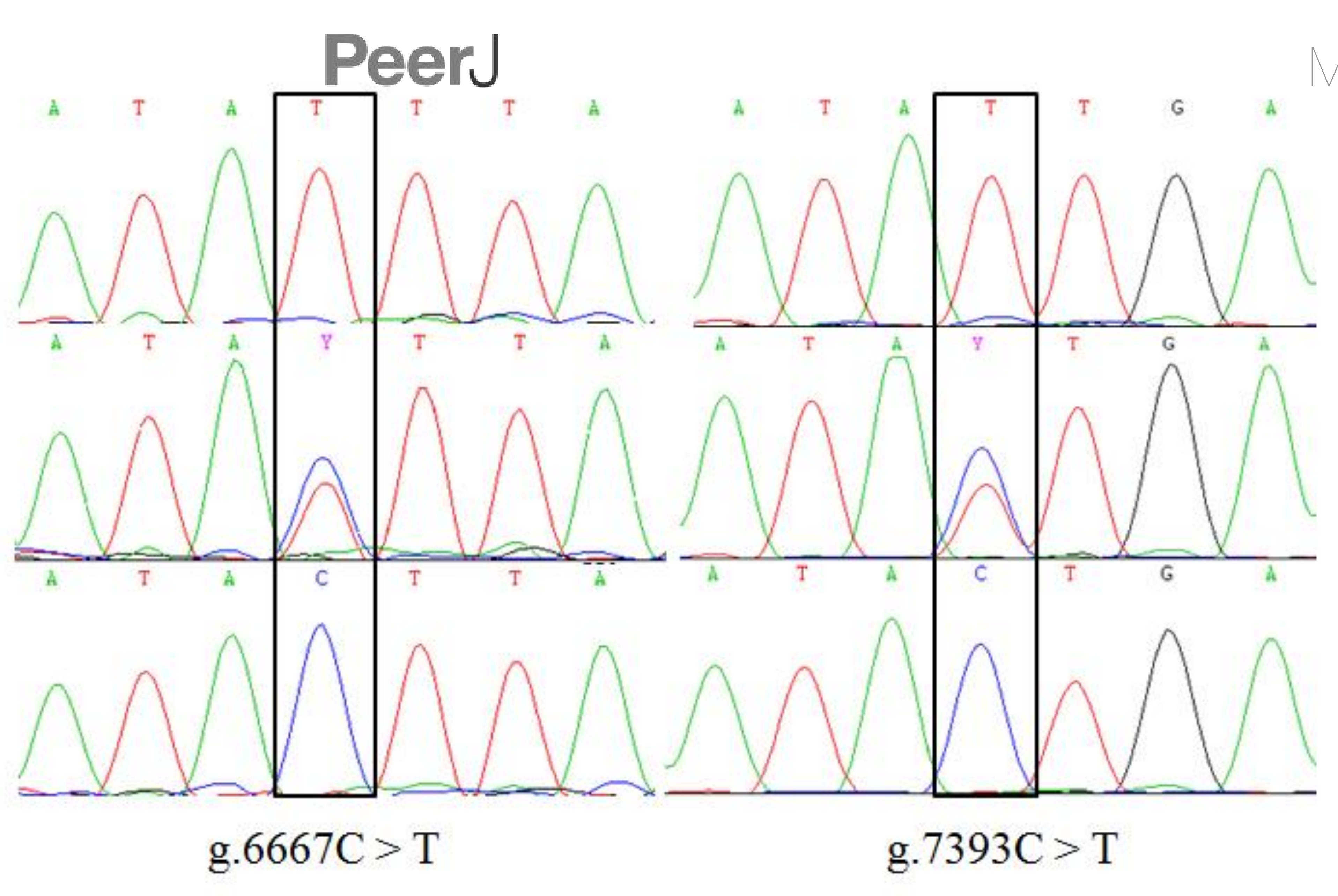

Manuscript to be reviewed
M TC TT TC
TC
TC
TC

A
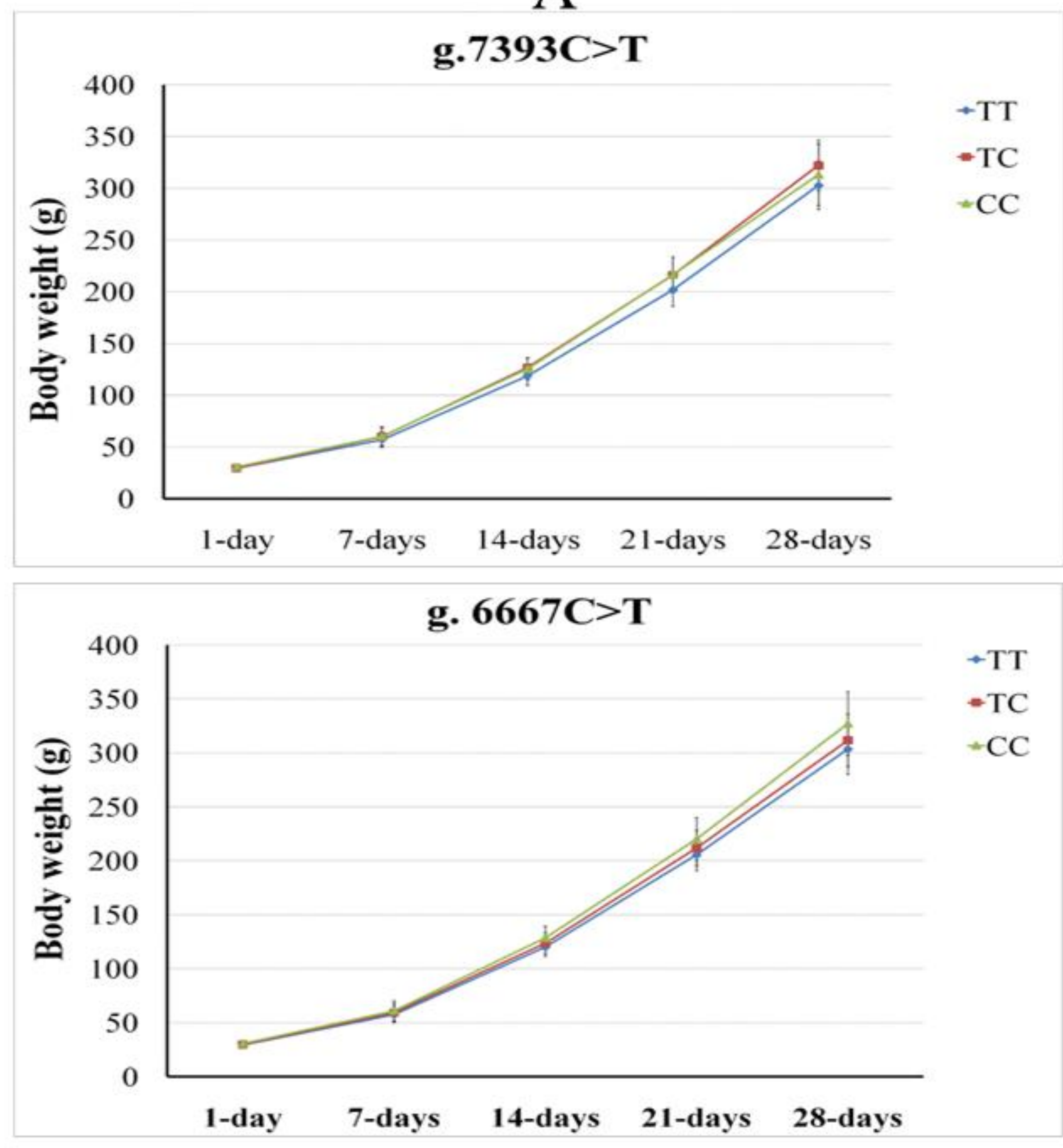

Peer) reviewCPPDF | (2016:02:9369:1:0:NEW 13 May 2016)

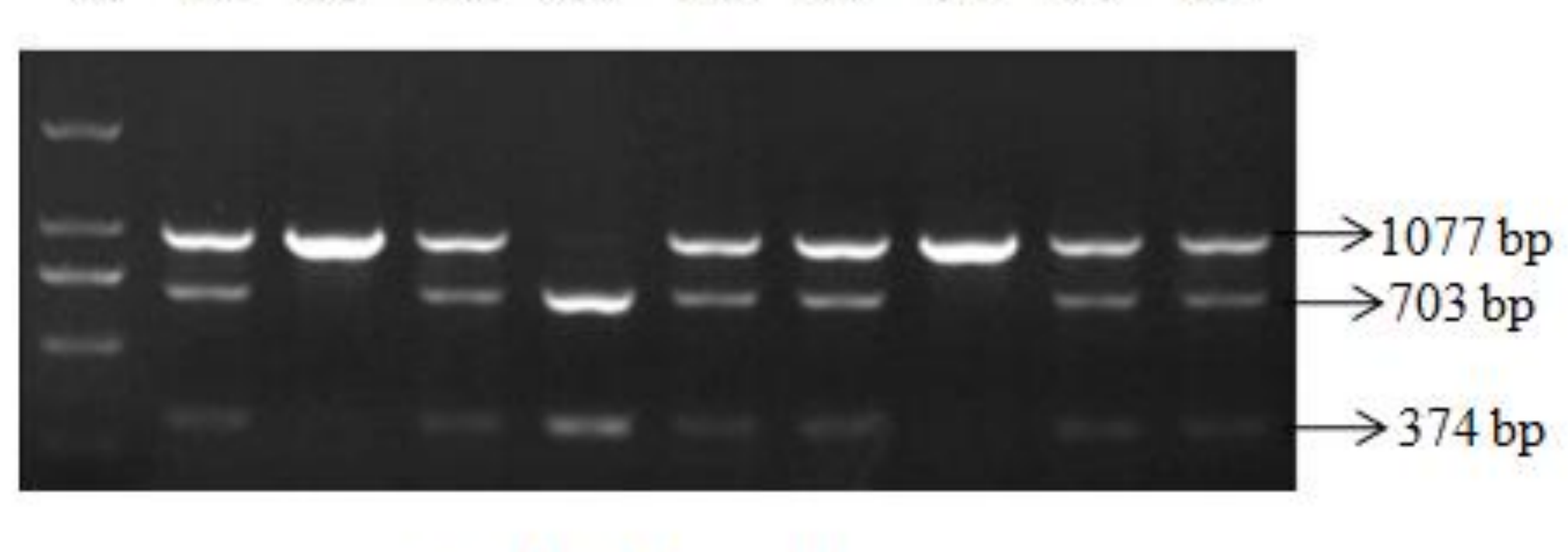$$
\text { g. } 6667 \mathrm{C}>\mathrm{T}
$$

M TC CC TC TC TT CC CC TT CC TT TT

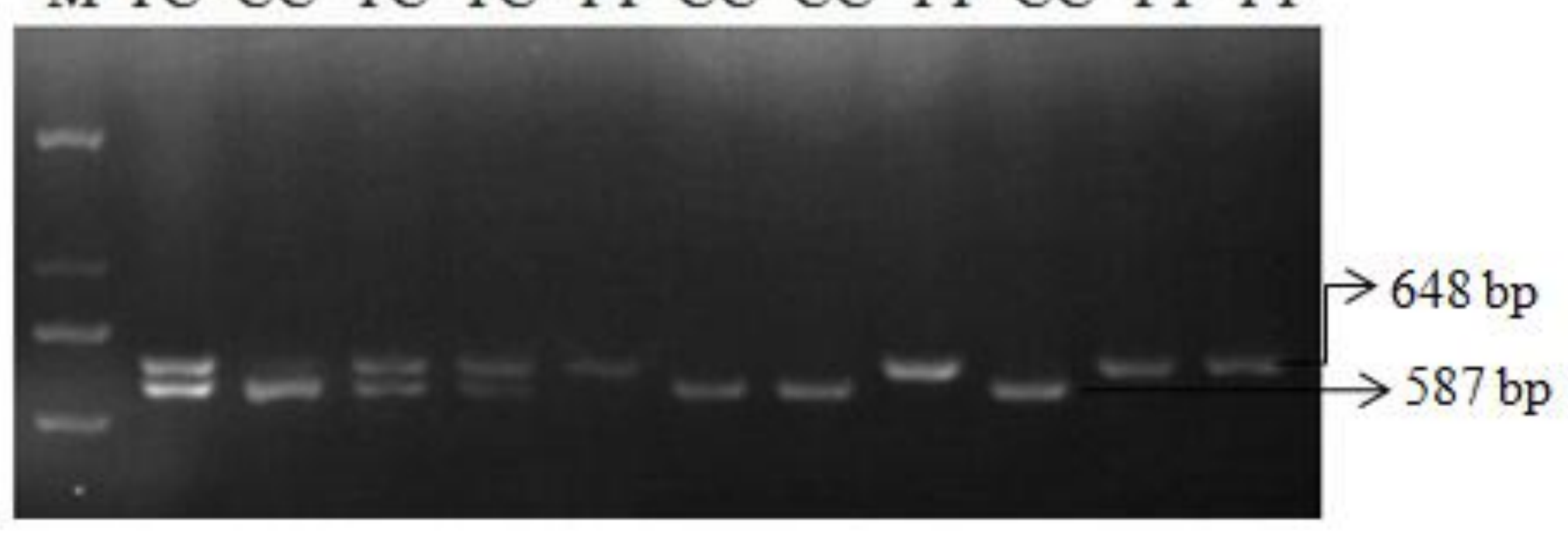

g. $7393 \mathrm{C}>\mathrm{T}$

B
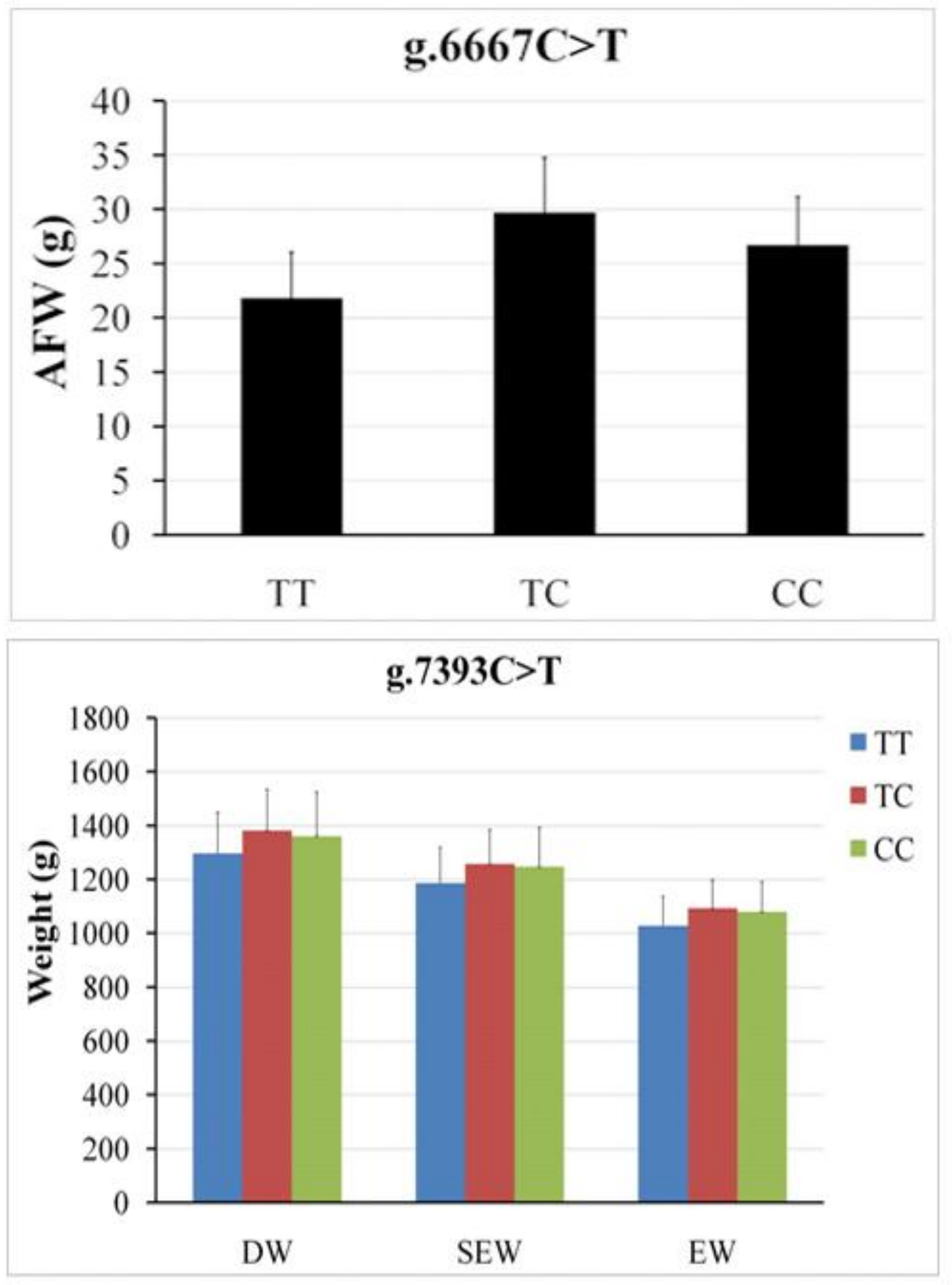

D 
Figure 3 (on next page)

Expression of GNPDA2 gene in adult XH chicken tissues.

The horizontal axis and vertical axis indicate different tissues and their mRNA relative expression values (mean \pm S.E.M). Cer, cerebrum; Ceb, cerebellum; Hyp, hypothalamus; Pit, pituitary; Abf, abdominal fat; Suf, subcutaneous fat; Chm, breast muscle; Hea, heart; Liv, liver;Spl, spleen; Lun, lung; Kid, kidney; Mst, muscular stomach; Gst, glandular stomach; Dub, duodenum; Tes, testis; Ova, ovary. 
Figure 4 (on next page)

The level of cGNPDA2 mRNA was regulated by body weight, feeding/fasting and by consumption of the high-glucose-fat diet.

(A) Level of CGNPDA2 mRNA in XH chickens of high and low body weight. (B) Level of cGNPDA2 mRNA in male and female XH chicken fed a basal diets and high-glucose-fat diets.

(C) Changes in the level of CGNPDA2 mRNA in XH chickens treated as control, fasted and Refed groups. Data are presented as the mean \pm S.E.M $(n=5),{ }^{*} P<0.05,{ }^{* *} P<0.01$. 
PeerJ
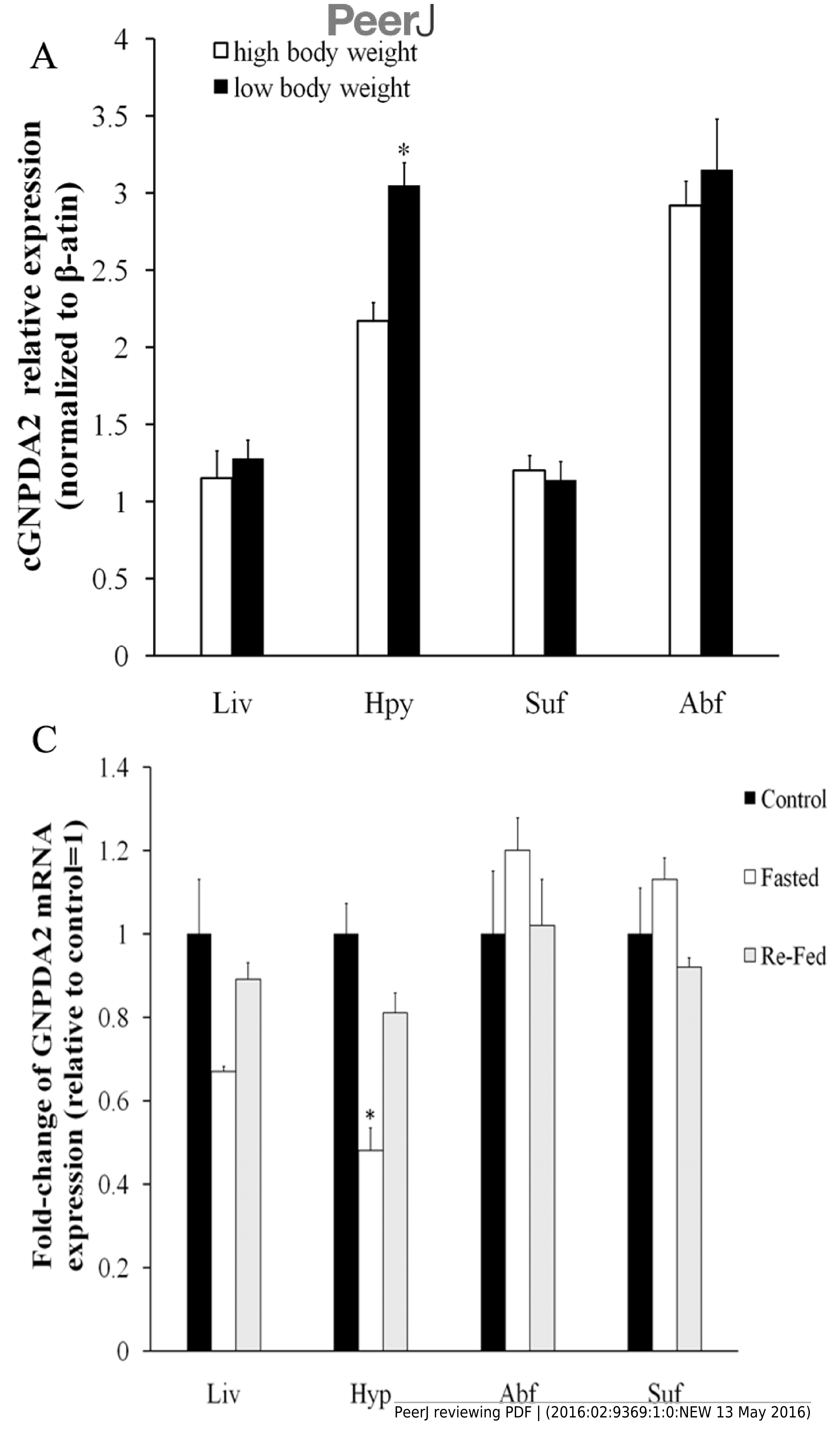
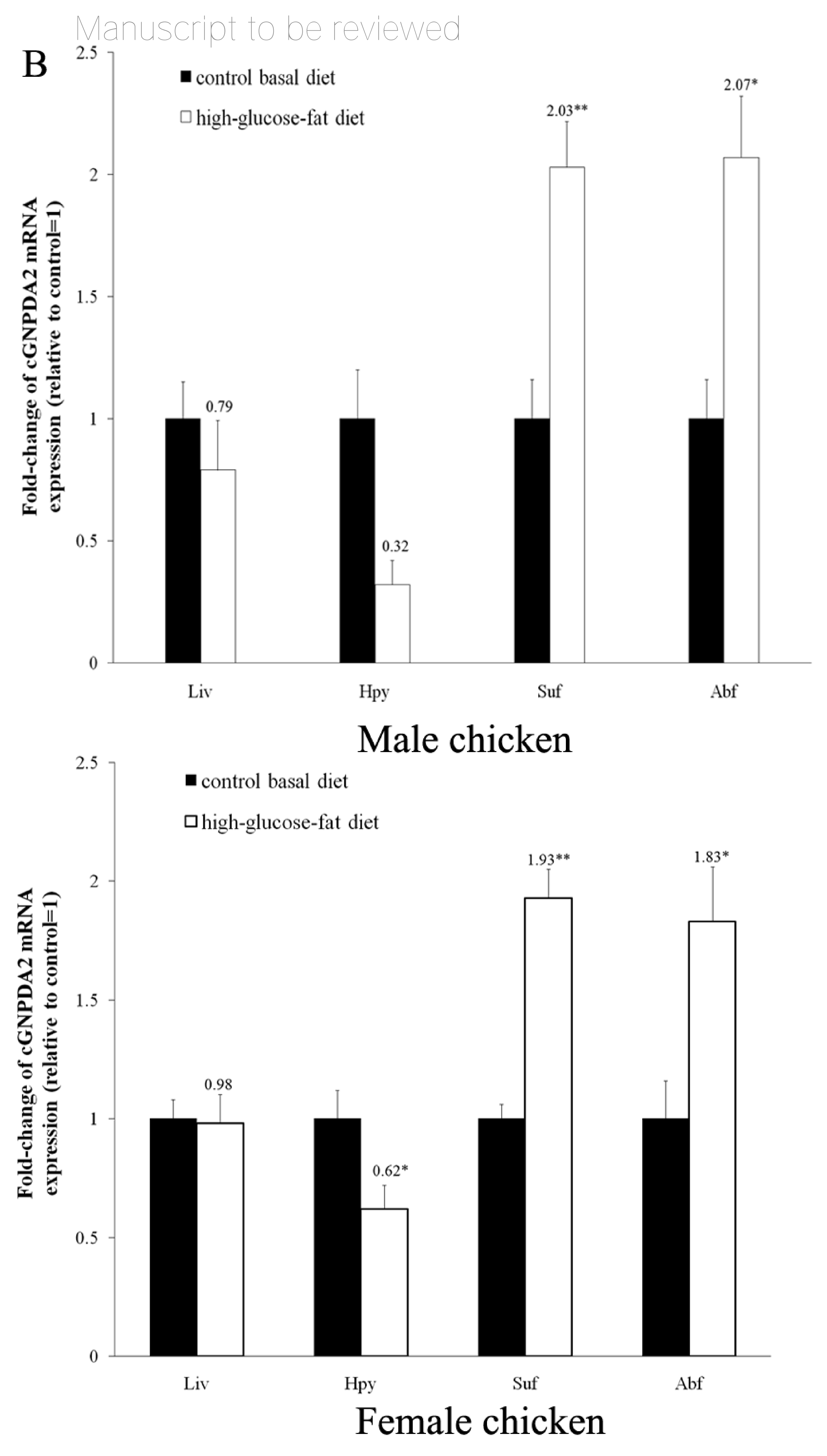
Figure $\mathbf{5}$ (on next page)

The different genotypes of g.6667C $>T$ and g.7393C $>T$ did not affected the expression of CGNPDA2.

(A) The genotypes of the chickens used for qPCR experiment. (B) The mRNA level of CGNPDA2 of three different genotypes of g.6667C > T in 25 23-weeks-old female chickens. (C) The mRNA level of CGNPDA2 of three different genotypes of g.7393C $>T$ in 25 23-weeks-old female chickens. 


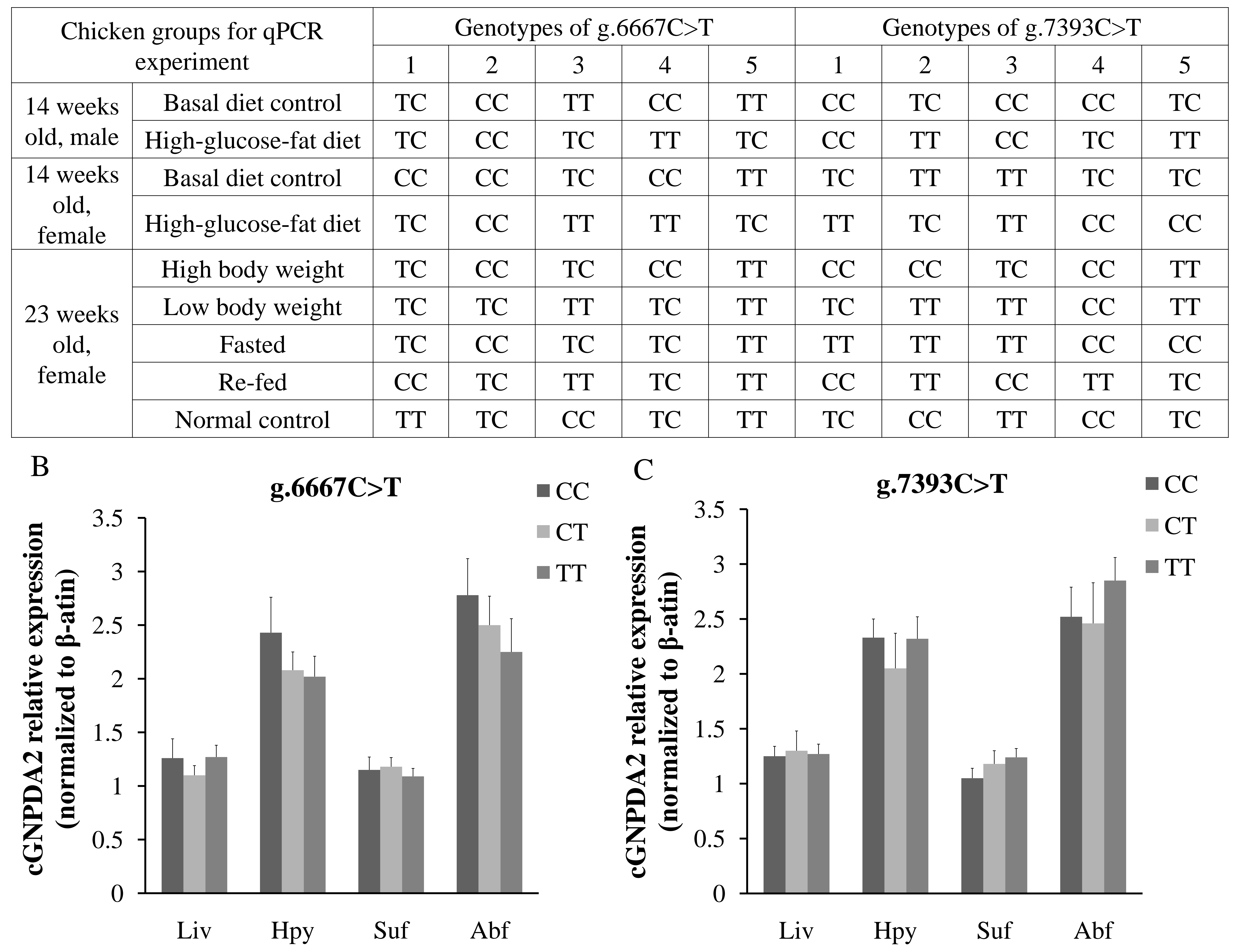




\section{Figure 6 (on next page)}

The changes of mRNA levels of related genes induced by cGNPDA2 overexpression (A) and siRNA interfering (B) in chicken preadipocytes.

Data are presented as the mean \pm S.E.M $(n=5),{ }^{*} P<0.05,{ }^{* *} P<0.01$. 


\section{Table 1 (on next page)}

25 SNPs identified in the full length of chicken GNPDA2 DNA sequence. 
1 Table 125 SNPs identified in the full length of chicken GNPDA2 DNA sequence.

\begin{tabular}{|c|c|c|c|c|}
\hline NO. & Site in DNA & SNPs & Region & NCBI number \\
\hline 1 & nt 1157 & $\mathrm{C} \rightarrow \mathrm{T}$ & Intron 1 & rs313319798 \\
\hline 2 & nt 1192 & $\mathrm{G} \rightarrow \mathrm{A}$ & Intron 1 & rs312694820 \\
\hline 3 & nt 1250 & $\mathrm{~A} \rightarrow \mathrm{T}$ & Intron 1 & - \\
\hline 4 & nt 1315 & $\mathrm{~T} \rightarrow \mathrm{C}$ & Intron 1 & rs313558025 \\
\hline 5 & nt 1347 & $\mathrm{G} \rightarrow \mathrm{A}$ & Intron 1 & - \\
\hline 6 & nt 2119 & $\mathrm{~T} \rightarrow \mathrm{C}$ & Exon 4 & rs316460349 \\
\hline 7 & nt 2412 & $\mathrm{G} \rightarrow \mathrm{A}$ & Exon 4 & rs316364048 \\
\hline 8 & nt 3404 & $\mathrm{~A} \rightarrow \mathrm{T}$ & Intron6 & rs14486231 \\
\hline 9 & nt 3590 & $\mathrm{C} \rightarrow \mathrm{T}$ & Intron 6 & rs312766474 \\
\hline 10 & nt 4231 & $-/ \mathrm{T}$ & Intron 6 & rs 14486233 \\
\hline 11 & nt 5436 & $A \rightarrow G$ & Intron 6 & rs317780046 \\
\hline 12 & nt 5527 & $\mathrm{~T} \rightarrow \mathrm{C}$ & Intron 6 & - \\
\hline 13 & nt 5605 & $A \rightarrow G$ & Intron 6 & rs317672439 \\
\hline 14 & nt 5659 & $A \rightarrow G$ & Intron 6 & rs312941054 \\
\hline 15 & nt 5841 & $\mathrm{C} \rightarrow \mathrm{G}$ & Intron 6 & rs312807283 \\
\hline 16 & nt 6091 & $\mathrm{C} \rightarrow \mathrm{G}$ & Intron 6 & rs794508049 \\
\hline 17 & nt 6098 & $\mathrm{C} \rightarrow \mathrm{T}$ & Intron 6 & - \\
\hline 18 & nt 6178 & $\mathrm{G} \rightarrow \mathrm{A}$ & Intron 6 & rs312926139 \\
\hline 19 & nt 6667 & $\mathrm{C} \rightarrow \mathrm{T}$ & 3’UTR & - \\
\hline 20 & nt 6822 & $\mathrm{~T} \rightarrow \mathrm{A}$ & 3’UTR & - \\
\hline 21 & nt 7090 & $\mathrm{~A} \rightarrow \mathrm{G}$ & 3'UTR & rs313999192 \\
\hline 22 & nt 7277 & $A \rightarrow G$ & 3’UTR & rs 14486237 \\
\hline 23 & nt 7306 & $\mathrm{~T} \rightarrow \mathrm{C}$ & 3’UTR & rs315312077 \\
\hline 24 & nt 7226 & $\mathrm{C} \rightarrow \mathrm{G}$ & 3'UTR & rs 14486238 \\
\hline 25 & nt 7393 & $\mathrm{C} \rightarrow \mathrm{T}$ & 3'UTR & rs 14486239 \\
\hline
\end{tabular}




\section{Table 2 (on next page)}

SNPS of GNPDA2 gene associated with growth and carcass traits in chicken.

Abbreviations: AFW, abdominal fat pad weight; BW21, BW1, BW7, BW14, BW21 and BW28 indicate body weight at 1,7,14, 21 and 28 days, respectively. CD, chest depth; DW, dressed weight; EW, eviscerated weight; LMW, leg muscle weight; SEW, semi-eviscerated weight; SIL, small intestine length. Statistical analysis was performed using GLM in SAS software (version 9.0), and data are shown as mean \pm S.E.M. Letters and numbers in brackets refer to genotype and number of chickens with that genotype. 
Table 2 SNPs of GNPDA2 gene associated with growth and carcass traits in chicken.

\begin{tabular}{|c|c|c|c|c|c|}
\hline \multirow{2}{*}{$\begin{array}{c}\text { Markers } \\
\text { g.6667C > T }\end{array}$} & \multirow{2}{*}{$\frac{\text { Traits }}{\mathrm{CD}(\mathrm{mm})}$} & \multirow{2}{*}{$\begin{array}{c}\text { P-value } \\
0.0117\end{array}$} & \multicolumn{3}{|c|}{ Least-squares mean \pm S.E.M } \\
\hline & & & $95.3 \pm 9.15(\mathrm{TT}, 117)$ & $96.6 \pm 9.26(\mathrm{TC}, 191)$ & $93.3 \pm 9.32(\mathrm{CC}, 108)$ \\
\hline & $\mathrm{AFW}(\mathrm{g})$ & 0.0006 & $21.8 \pm 4.23(\mathrm{TT}, 113)$ & $29.7 \pm 5.05(\mathrm{TC}, 185)$ & $26.7 \pm 4.46(\mathrm{CC}, 107)$ \\
\hline & BW1 (g) & 0.0019 & $29.5 \pm 2.40(\mathrm{TT}, 117)$ & $29.7 \pm 2.81(\mathrm{TC}, 191)$ & $30.7 \pm 2.74(\mathrm{CC}, 108)$ \\
\hline & BW7 (g) & 0.0347 & $57.6 \pm 7.63(\mathrm{TT}, 117)$ & $59.3 \pm 8.50(\mathrm{TC}, 191)$ & $61.1 \pm 9.12(\mathrm{CC}, 108)$ \\
\hline & BW14 (g) & 0.0128 & $120.1 \pm 8.68(\mathrm{TT}, 117)$ & $123.6 \pm 9.61(\mathrm{TC}, 191)$ & $128.7 \pm 10.53(\mathrm{CC}, 108)$ \\
\hline & BW21 (g) & 0.0049 & $205.5 \pm 14.80(\mathrm{TT}, 117)$ & $211.8 \pm 16.47(\mathrm{TC}, 191)$ & $220.2 \pm 19.81(\mathrm{CC}, 108)$ \\
\hline & BW28 (g) & 0.0078 & $303.4 \pm 23.35(\mathrm{TT}, 117)$ & $311.7 \pm 24.41(\mathrm{TC}, 191)$ & $327.1 \pm 29.58(\mathrm{CC}, 108)$ \\
\hline \multirow[t]{8}{*}{ g. $7393 \mathrm{C}>\mathrm{T}$} & DW (g) & 0.0114 & $1296.3 \pm 153.9(\mathrm{TT}, 115)$ & $1381.2 \pm 153.7(\mathrm{TC}, 130)$ & $1360.9 \pm 164.7(\mathrm{CC}, 171)$ \\
\hline & SEW (g) & 0.0026 & $1186.4 \pm 133.8(\mathrm{TT}, 115)$ & $1257.7 \pm 126.3(\mathrm{TC}, 130)$ & $1246.9 \pm 144.7(\mathrm{CC}, 171)$ \\
\hline & EW (g) & 0.0043 & $1027.6 \pm 109.7(\mathrm{TT}, 115)$ & $1092.0 \pm 105.5(\mathrm{TC}, 130)$ & $1079.0 \pm 112.6(\mathrm{CC}, 171)$ \\
\hline & LMW (g) & 0.0163 & $113.5 \pm 12.6(\mathrm{TT}, 115)$ & $119.1 \pm 12.5(\mathrm{TC}, 130)$ & $119.0 \pm 14.9(\mathrm{CC}, 171)$ \\
\hline & SIL (cm) & 0.0183 & $136.7 \pm 11.4 \quad(\mathrm{TT}, 110)$ & $144.5 \pm 13.4(\mathrm{TC}, 121)$ & $139.4 \pm 10.8(\mathrm{CC}, 163)$ \\
\hline & BW14 (g) & 0.0342 & $118.7 \pm 9.06(\mathrm{TT}, 115)$ & $126.7 \pm 10.49(\mathrm{TC}, 130)$ & $125.3 \pm 9.40(\mathrm{CC}, 171)$ \\
\hline & BW21 (g) & 0.0045 & $201.8 \pm 15.99(\mathrm{TT}, 115)$ & $216.0 \pm 17.61(\mathrm{TC}, 130)$ & $216.2 \pm 17.29(\mathrm{CC}, 171)$ \\
\hline & BW28 (g) & 0.0488 & $302.7 \pm 23.42(\mathrm{TT}, 115)$ & $322.1 \pm 24.84(\mathrm{TC}, 130)$ & $313.1 \pm 27.23(\mathrm{CC}, 171)$ \\
\hline
\end{tabular}

Abbreviations: AFW, abdominal fat pad weight; BW21, BW1, BW7, BW14, BW21 and BW28 indicate body weight at 1,7,14, 21 and 28 days, respectively. CD, chest depth; DW, dressed weight; EW, eviscerated weight; LMW, leg muscle weight; SEW, semi-

eviscerated weight; SIL, small intestine length. Statistical analysis was performed using GLM in SAS software (version 9.0), and data are shown as mean \pm S.E.M. Letters and numbers in bracket refer to genotype and number of chickens with that genotype. 